\title{
11. Economic and social convergence in Spain: The elusive goal of catching up with the EU Rafael Muñoz de Bustillo
}

\section{INTRODUCTION}

At the time of writing Spain is celebrating the fortieth anniversary of its first democratic general elections after four decades of dictatorship. The process of transition to democracy inaugurated with these elections had a clear and widely shared goal: convergence with the rest of Europe. A saying popular in the twentieth century and especially at the time of elections - 'Europe starts in the Pyrenees' - perfectly reflects such a feeling. For many Spaniards, Europe represented the model in economic and social development, not to mention political and civil rights consolidation (Juliá 2018). That explains why Spain was, and still is, among the most pro-European countries in the EU. ${ }^{1}$ Forty years later Spain is a very different country, but full convergence is still far away. In the meantime, things have changed in the EU, in both size and backing, with growing numbers of Europeans questioning the road it seems to them to have taken.

The purpose of this chapter is to study the extent to which there has been social and economic convergence in Spain towards the EU, both in results and institutions, paying special attention to the role played by the industrial relations system. With that aim we look at convergence of results and instruments. In that spirit, in section 2 we will evaluate the process of economic convergence, including income as well as convergence in employment and productivity, the two sources of gross domestic product (GDP) growth. In section 3 we will look at convergence from a social perspective, paying attention to the late development of the Spanish welfare state and the results achieved for poverty and (in)equality. This section also looks at the issue through the eyes of an alternative indicator of economic well-being. While up to now the focus of our investigation has been Spain in relation to the European Union (EU), in section 4 we will look at convergence within Spain in order to see how the different regions have fared. In section 5 we change the focus, looking at convergence from the perspective of institutions. Since the creation of the Economic and Monetary Union (EMU), the EU has increased, by various means, its role in the coordination of member states' economic and social policy. The different tools of economic governance of the European Semester are a good example of this. We review the extent to which this has contributed to policy convergence, looking at three specific items related to the labour market and industrial relations: minimum wage, unemployment benefits and non-standard employment. In section 6 we will take a closer look at the swift convergence regarding immigration rates that to a considerable extent took Spain by surprise at the turn of the twenty-first century, paying special attention to the role of social actors. Finally, section 7 presents the main conclusions. 


\section{ECONOMIC CONVERGENCE}

According to standard neoclassical growth theory, economic convergence is important to capitalism's identity. Low-income countries or regions are so because of lower productivity, related to lower capital-labour ratios. According to the principle of diminishing returns, in regions with lower capital endowments, capital would enjoy higher returns, which incentivises investment. The increase in investment, in turn, would lead to higher capital-labour ratios and productivity, ushering in higher GDP growth and convergence. In this, convergence would be a matter of time, and countries would be expected to reduce their differences in per capita GDP to those explained by differences in employment levels. ${ }^{2}$ Unfortunately, investment, and therefore growth, is affected by many other variables, from those related to geography and institutions to those associated with human or natural capital endowments. The existence of other elements that can hinder economic convergence has been, if reluctantly, acknowledged by standard neoclassical theory in the concept of conditional convergence. This means that countries converge in growth rates but not in capital/labour ratios or per capita GDP, as a result of their specific circumstances in all the variables affecting growth. Such conditional convergence, which does not guarantee the equalisation of per capita GDP, is little consolation for less developed countries.

We start our overview of economic convergence in Spain from a long-run perspective. To do so, we have constructed a long-run series of per capita GDP, from 1850 to 2016, ${ }^{3}$ of five relevant EU countries: the United Kingdom, Germany, France, Italy and Sweden (from here on, the Big Five) and Spain. We use the simple average of national per capita GDP (in US\$ purchasing power parity, PPP) in the Big Five as a benchmark against which to gauge the long-run convergence of the Spanish economy.

Figure 11.1 presents convergence (or the lack of it) in two different ways. Figure 11.1a shows the evolution of the average GDP of the Big Five together with the Spanish per capita GDP expressed as a percentage of the average of the per capita GDP of the Big Five. Figure $11.1 \mathrm{~b}$ presents two of the most common measures of convergence used in the literature, the coefficient of variation $(\mathrm{CV})$ of per capita GDP, a relative indicator of convergence (known as sigma convergence), and the standard deviation of per capita GDP (STD), a well-known and widely used index of absolute dispersion.

Starting with Figure 11.1a, focusing on Spain's per capita GDP measured against the Big Five average - an indicator of convergence/divergence - we can see five different phases:

1. 1850-1930, characterised by fluctuations around the historical gap, around 20-30 percentage points.

2. 1930-60, the Big Drop: Spanish per capita GDP fell and then remained stagnant in a context of GDP growth in the Big Five, resulting in an increase in the per capita GDP gap of up to 50 per cent.

3. 1960-90, the development decades, but a successful transition and joining the EU allow a reduction of the gap to 20 per cent.

4. 1990-2007, slow but sure growth pushes the gap down to 12 per cent, the lowest since 1850 .

5. 2008-13, the Big Dip, with the Great Recession in just four years the gap in per capita 

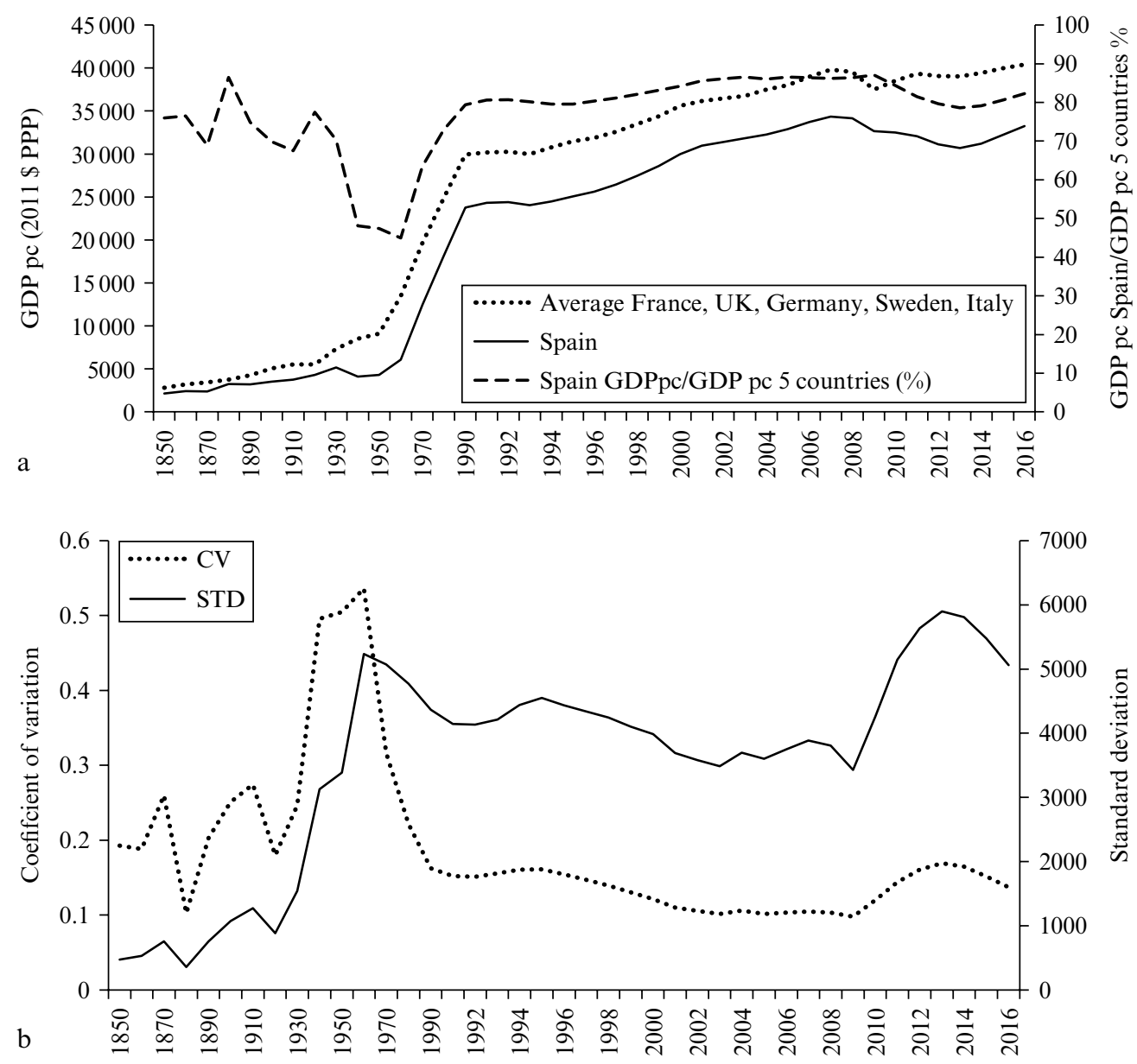

Note: $\mathrm{pc}=$ per capita.

Source: Author analysis on World Development Indicators, and Bolt et al. (2014, p. 67).

Figure 11.1 Long-term convergence between Spain and the average of five European countries, 1850-2016

GDP grows by 8.5 percentage points, taking the country back two decades in per capita GDP convergence. Since 2014, however, the economic recovery reduced the gap to 5 percentage points.

Figure $11.1 \mathrm{~b}$ confirms the periods described above. Of particular note is the much lower convergence from the 1960s until the end of the 1990s measured in absolute convergence compared with relative convergence. This is a constant of most analysis of convergence; reducing absolute differences in GDP is much more difficult than reducing relative differences in GDP. This is important because to most people the absolute 
difference - the euro-gap between per capita GDPs - is a more relevant measure of inequality than the relative difference.

In summary, although the Spanish economy was able to multiply its per capita income by five from 1960 to the Great Recession - almost twice as fast as its closest competitor (Italy) in our country sample - such impressive growth was not enough to catch up with the EU core countries. Moreover, the long, harsh crisis of 2009-13 made a profound dent in this accomplishment, setting the clock back more than a decade.

As mentioned previously, the evolution of per capita GDP can be tautologically explained by the evolution of productivity and employment rates. From this perspective, the analysis of Spanish convergence over the past half-century is revealing, as we can find two distinct phases of employment-driven and productivity-driven growth and convergence. As we can see in Figure 11.2, which presents the evolution of productivity and employment growth from 1970 to 2016, the first phase of economic growth and convergence was almost entirely driven by productivity growth, in a context of almost stagnant employment (in 1970 total employment in Spain was 12.8 million, roughly the same as 20 years later, with 13.2 million). In sharp contrast, in the second phase, from the recovery from the 1993 crisis to the beginning of the Great Recession in 2009, convergence was almost solely driven by employment growth in a context of quasi-stagnant productivity. With the coming of the crisis, as in 1993, we observe higher employment destruction than GDP reduction, leading to increasing productivity.

The substitution of productivity-led growth for employment-led growth explains Spain's relatively poor productivity performance vis-à-vis the EU15. As we can see in Table 11.1, although in 2005 the level of average productivity in Spain was close to the EU27 average, compared with EU15 member states, in all cases except Portugal and Greece, and for all sectors except non-market services, Spanish labour productivity is significantly lower than in the rest of the non-Mediterranean EU15 countries: 29 per cent lower than in France, 19 per cent lower than in Denmark and 12 per cent lower than in the United Kingdom.

Looking at the supply side, Figure 11.3 presents the evolution - focusing on the past two decades - of all the variables behind the index of total employment (total employment divided by population), namely: Figure 11.3a, demographic structure (potential labour force, between 16 and 64 years of age, in relation to population); Figure 11.3b, labour force participation rate (labour force relative to potential labour force); Figure 11.3c, employment rate (employment relative to labour force); and finally, Figure 11.3d, total employment rate (employment relative to total population). For the purpose of comparison, the Spanish data are benchmarked against the EU15 average and Sweden, a country that ranks very highly in employment and labour force participation rates. At the beginning of the period, Spain had a more favourable demographic structure (in potential labour force), but lower labour force participation and employment rates, leading to a lower total employment rate (in relation to total population).

The period exhibits convergence in all variables up until the Great Recession, when full convergence in total employment rate with the EU15 is almost achieved (although in relation to Sweden, even at its highest, Spain's total employment rate was still 10 per cent lower). However, the crisis produced a radical change of trend, leading to a huge drop 
a) Employment growth (\%)

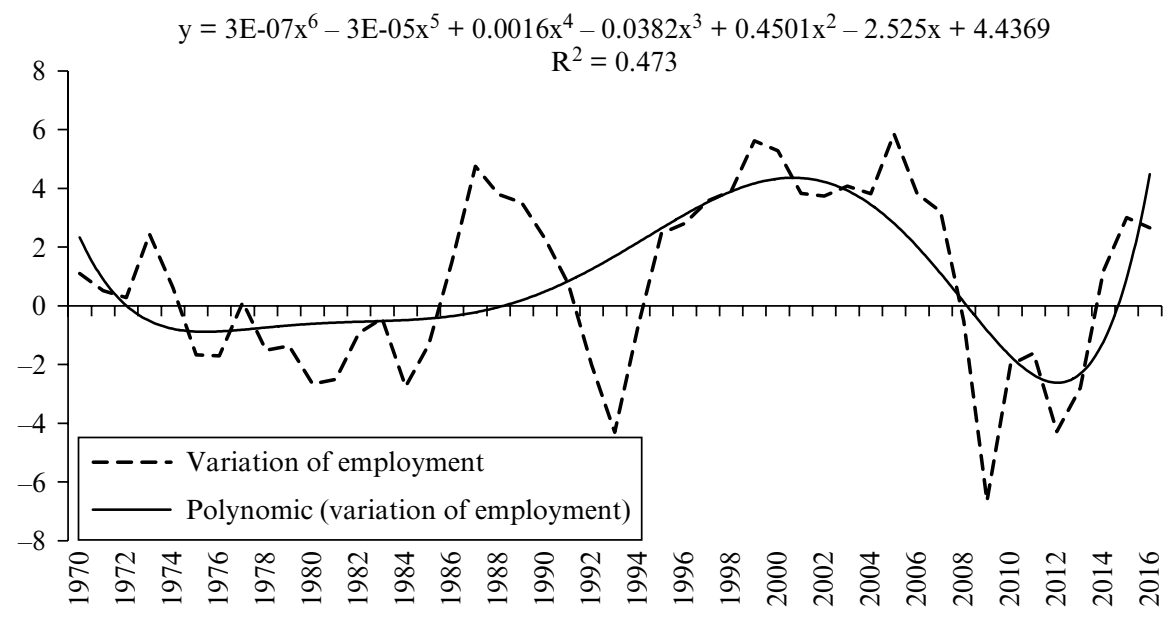

b) Productivity growth (\%)

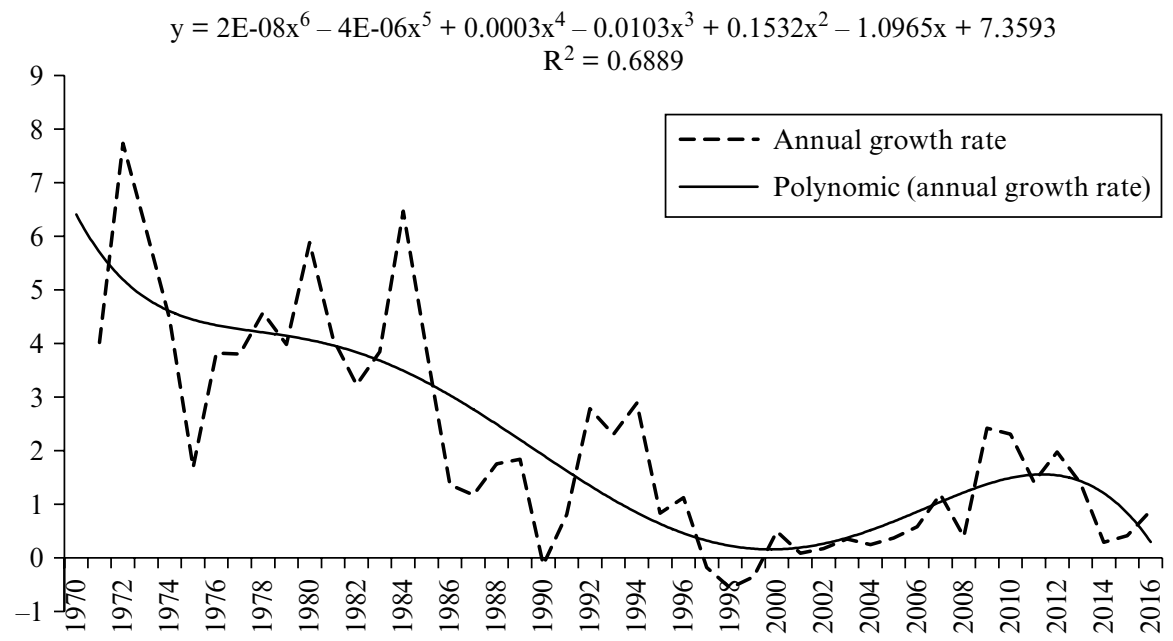

Source: Author's analysis of OECD (2017, p. 18), OECD Labour Statistics and Encuesta de Población Activa (EPA).

Figure 11.2 Employment and productivity growth, Spain, 1970-2016

in the total employment rate as a result of the gargantuan increase in unemployment and the corresponding decrease in employment rates, taking Spain back to the year 2000 level in convergence with the EU15. In summary, we can observe an intensive process of convergence of all labour variables affecting per capita GDP, brusquely interrupted by the Great Recession. It is important to stress that this interruption affects only the employment rate, not labour force participation. 
Table 11.1 GDP and major sector labour productivity (value added per hour worked), Spain and EU15, 2005 (EU27 = 100)

\begin{tabular}{lrcccrrrr}
\hline Country & GDP & $\begin{array}{c}\text { Market } \\
\text { economy }\end{array}$ & $\begin{array}{c}\text { Goods } \\
\text { production }\end{array}$ & Manufacturing & $\begin{array}{r}\text { Other } \\
\text { goods }\end{array}$ & Services & $\begin{array}{c}\text { Market } \\
\text { services }\end{array}$ & $\begin{array}{c}\text { Non- } \\
\text { market } \\
\text { services }\end{array}$ \\
\hline Luxembourg & 161.0 & 169.8 & 115.3 & 120.4 & 116.8 & 175.9 & 197.4 & 135.3 \\
Belgium & 147.4 & 163.2 & 195.7 & 165.4 & 225.8 & 132.3 & 147.8 & 108.5 \\
France & 136.2 & 136.1 & 150.5 & 141.2 & 165.3 & 130.9 & 128.6 & 132.0 \\
Netherlands & 134.5 & 146.6 & 178.9 & 182.5 & 168.6 & 120.1 & 131.8 & 101.3 \\
Germany & 127.6 & 132.7 & 157.6 & 150.3 & 103.5 & 115.1 & 116.4 & 112.7 \\
Sweden & 125.5 & 138.1 & 156.0 & 149.0 & 121.5 & 113.3 & 124.7 & 96.2 \\
Ireland & 125.1 & 139.5 & 156.1 & 236.8 & 70.2 & 107.9 & 124.4 & 80.2 \\
Denmark & 119.8 & 135.4 & 174.8 & 139.6 & 251.0 & 101.4 & 112.4 & 85.0 \\
Austria & 117.5 & 113.6 & 119.4 & 140.5 & 87.1 & 116.6 & 108.9 & 131.8 \\
Finland & 111.8 & 123.9 & 152.5 & 166.1 & 125.0 & 91.8 & 97.7 & 81.6 \\
United & 111.0 & 129.0 & 162.2 & 139.7 & 208.9 & 98.2 & 116.1 & 72.9 \\
$\quad$ Kingdom & & & & & & & & \\
Italy & 105.1 & 97.6 & 110.1 & 99.6 & 120.2 & 102.6 & 89.4 & 148.3 \\
Spain & $\mathbf{9 7 . 0}$ & $\mathbf{9 3 . 2}$ & $\mathbf{9 6 . 0}$ & $\mathbf{9 5 . 8}$ & $\mathbf{1 1 2 . 1}$ & $\mathbf{9 7 . 6}$ & $\mathbf{9 0 . 9}$ & $\mathbf{1 1 4 . 4}$ \\
Greece & 76.4 & 71.3 & 60.6 & 57.0 & 83.2 & 83.7 & 78.6 & 102.3 \\
Portugal & 55.7 & 54.7 & 48.2 & 46.8 & 59.7 & 61.2 & 61.1 & 64.0 \\
\hline
\end{tabular}

Source: Author's analysis from Inklaar and Timmer (2012).

As per capita GDP growth is the product of growth in the rate of total employment and of labour productivity, for a given rate of growth higher convergence in one of the indicators will necessarily be produced at the cost of lower convergence in the other indicator. After the crisis, from a social and political point of view, employment growth has had the highest priority. With employment growth rates close to GDP growth rates, the years of economic recovery are witnessing convergence in employment in a context of stagnant productivity.

What was the role of industrial relations in this process of convergence? As argued elsewhere (Muñoz de Bustillo and Pinto 2017), Spanish trade unions played an important role in facilitating the economic and social transition to democracy in the late 1970s and early 1980s. To the extent that the success of such a transition was a necessary condition for continuing convergence, we could say, loosely, that the industrial relations system played a functional role.

From a different perspective, during the last wave of GDP growth and employment creation that started in the mid-1990s and ended with the Great Recession, various institutions and governments argued that wage moderation was crucial for employment creation. For example, to name just two, in its 2001 report on the economic situation in Spain (OECD 2001), the Organisation for Economic Co-operation and Development (OECD) stressed that Spanish economic growth depended on 'strict maintenance of wage moderation' (OECD 2001, p. 42). Similarly, in its 2002 Annual Report, the Bank of Spain stressed that in order to consolidate economic recovery it was necessary to 'resume the pattern of wage moderation' (Banco de España 2002, p. 24). The industrial relations 
Potential labour force as percentage of total population

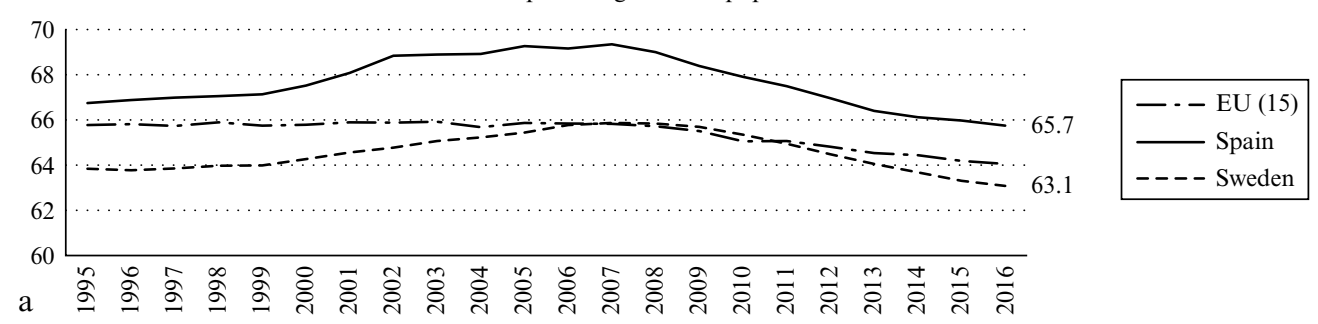

Labour force participation rate

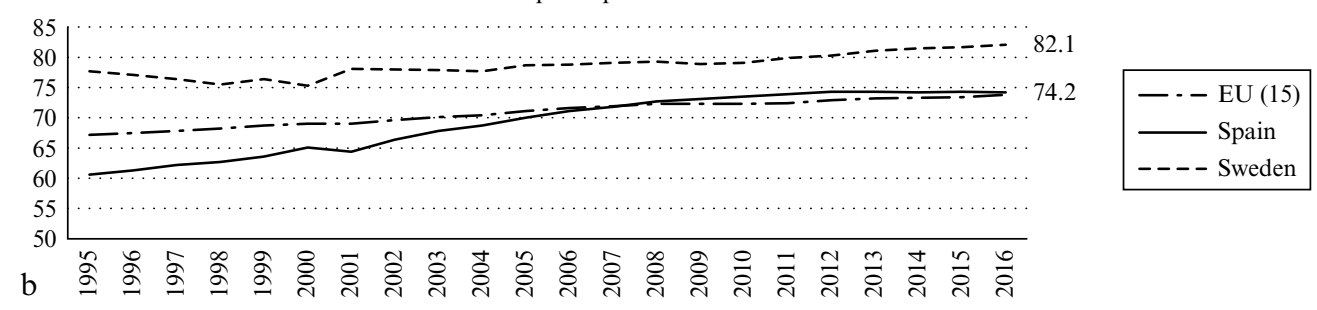

Employment rate (employment/labour force \%)

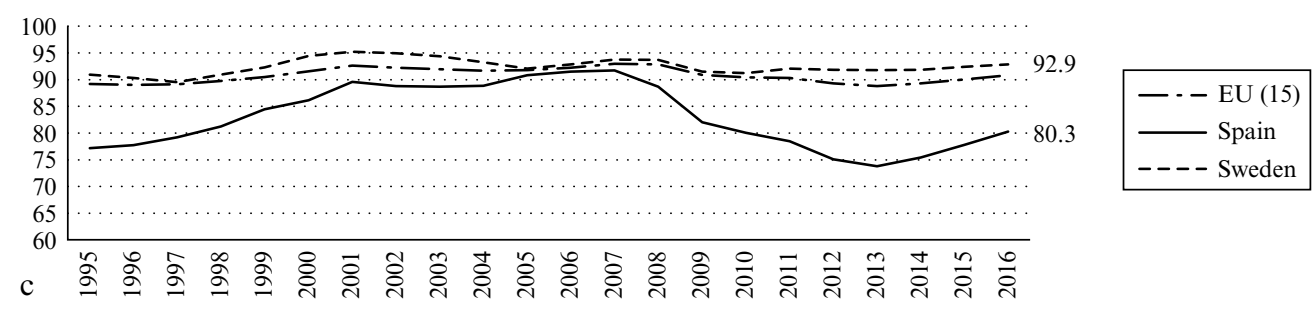

Total employment rate (employment/population, percentage)

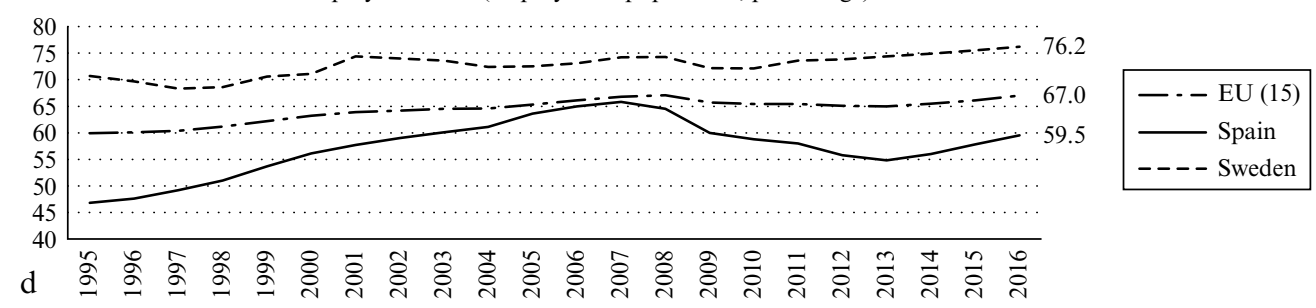

Source: Author's analysis from Eurostat (European Labour Force Survey, ELFS) and the Instituto Nacional de Estadística National (INE, National Statistics Institute of Spain) (EPA) data.

Figure 11.3 Convergence from a labour perspective, Spain, 1995-2016

system is just one of the elements behind wage moderation. Many other things, such as the unemployment rate, rising labour supply (resulting from growing immigration and female labour force participation), labour regulation reforms, and so on, affect wage trends. If we review both trade union documents and the results of different framework agreements at the national level, wage moderation seems to have been a major element in bargaining. 
A different issue, which unfortunately is beyond the scope of this chapter, is whether the positive impact - in higher profitability and hopefully higher investment and employment, as well as higher competitiveness - of wage moderation on GDP and employment growth (and therefore on convergence) was strong enough to compensate for the potential negative implications of such a policy, such as lower incentives to invest in innovations, lower productivity growth, lower increase in domestic consumer demand and so on. ${ }^{4}$

In summary, in the past few decades Spain has experienced convergence in income per capita towards the EU15, fuelled initially by productivity growth and more recently by employment growth. This process was abruptly halted by the Great Recession, which gave way to a lost decade in which convergence was replaced by divergence. Just before the crisis, measured against the EU15, Spain had achieved convergence in total employment rates - albeit in a context of still high unemployment rates - and thus income differences were explained mainly by lower productivity. The crisis changed this situation, adding, on top of the productivity gap, a sizeable gap in total employment rates.

\section{SOCIAL CONVERGENCE}

Our review of Spain's social convergence towards the EU15 will focus on three items: social expenditure, income inequality and poverty rates. Our interest in social expenditure is explained by the important role played by the modern welfare state in allowing better coverage of social needs through various social protection programmes both in cash (unemployment benefits, pensions, and so on) and in kind (for example, health care and housing). Income inequality and poverty rates are two different expressions of how well (or badly) the growing output associated with economic convergence is distributed among the population, whether it follows parameters similar to the EU or not. Compared with the United States, European societies have always been distinguished by their lower inequality and more developed welfare states. These characteristics are necessarily interconnected because social expenditure is a major element in lower inequality and poverty rates.

Starting with social protection, it is a well-established fact of comparative social system research that in the EU there are different 'models' of social protection and different levels of development of the welfare state. Regardless of the specific nomenclature (familistic, Mediterranean, and so on) all classifications consider Spain to be at the lower end in social protection from a EU perspective (Ferrera 1996; Moreno 2009). The relatively small size of the welfare state - before the Great Recession social expenditure was around 20 per cent of GDP, compared with 26 per cent for the EU15 - is partly explained by its late development, in the final years of Franco's dictatorships and the first years of the democratic transition, in a context of serious economic hardship. Nevertheless, as we can see in Figure 11.4 - in which Spanish social expenditure as a percentage of GDP is represented together with the EU15 average and the maximum and minimum values of social expenditure for the EU27 - Spain does not exhibit convergence towards the EU15 in the late 1990s period of high economic growth; quite the opposite. Only with the recession, and mainly owing to the drop in GDP, did the share of social expenditure in GDP rise from 20 to 25 per cent (even in a context of sizeable cuts in social expenditure and austerity). This paradoxical convergence in social protection (in a time of troubles, not of abundance) will probably be 


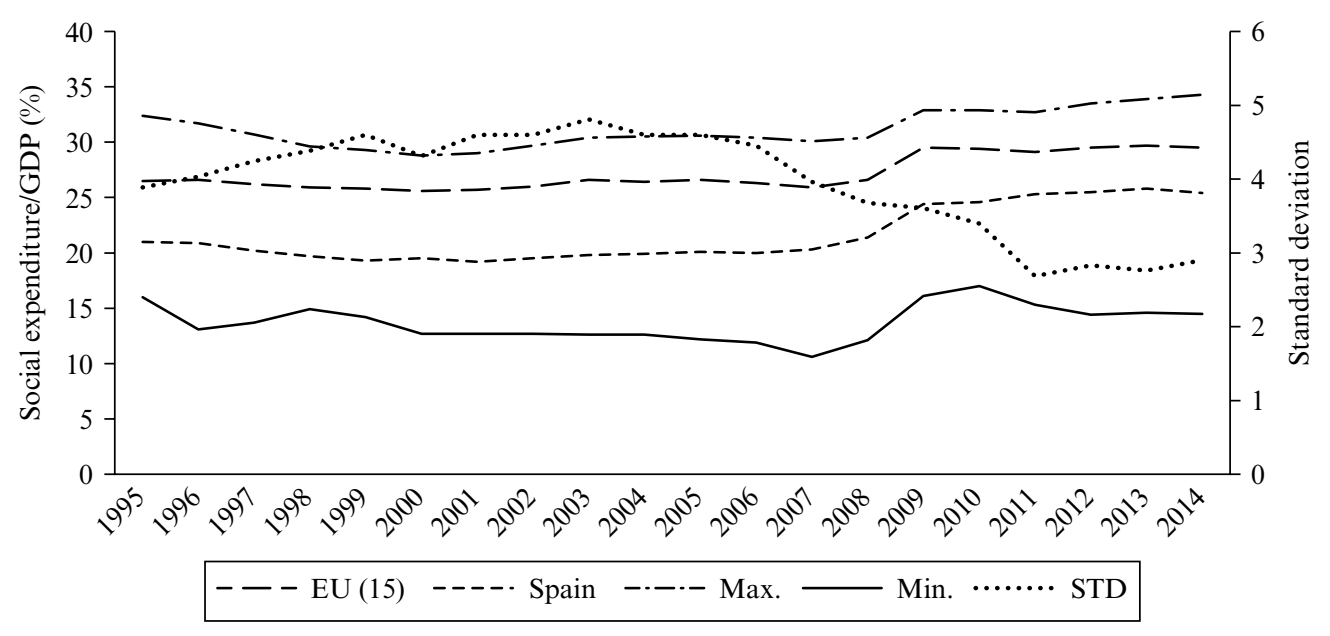

Source: Author's analysis from Statistics on Income and Living Conditions (SILC) (Eurostat).

Figure 11.4 Social expenditure as a percentage of GDP, EU15, Spain and country with the maximum and minimum indicator, 1995-2014

short lived, as shown by the Stability Program Update for the Kingdom of Spain 20172020 (Government of Spain 2017, p. 98), in which social expenditure (health care, social protection and housing) as a percentage of GDP is expected to drop to 21.9 per cent by 2020. This intention reveals that the lack of convergence in social expenditure was policy driven; the result of political will and not the consequence of a lack of resources needed to further develop the Spanish welfare state. This lack of convergence in social expenditure is a second important element of our analysis. It shows how social convergence - at least in relative resources allocated to social protection - has been decoupled from economic growth, as social expenditure as a share of GDP remained stagnant during more than a decade of high GDP and employment growth.

The gap between the resources of the Spanish social protection system and the EU average has been a cause for concern among the trade unions, who have called for the gap to be narrowed on various occasions. An example of such attempts is the Propuesta Sindical Prioritaria (Priority Trade Union Proposal), a programme of action signed by the two major trade union confederations in 1989, with a wide list of demands aimed at improving the social protection system and reducing inequality, among other goals more closely related to the labour market. One such demand was the creation of a system of non-contributory universal pensions for retirees with no access to standard contributory retirement pensions. This programme of action was the expression of the longing of a large part of the population for a 'social turn' or 'Giro social' as a type of compensation for a long decade of economic sacrifices, at a moment when the economy was doing well. In 1990 the government approved the creation of a system of non-contributory pensions that, for many years (until approval in 2006 of the Law on Dependence), was the last major improvement of the Spanish protection system. ${ }^{5}$ More recently (in 2014), the trade unions reached an agreement with the conservative government to extend the unemployment protection system to 
long-term unemployed workers who had terminated their non-contributory unemployment assistance owing to the intensity and duration of the crisis. Finally, the trade unions are also deeply engaged in the debate on the need to create a guaranteed minimum income to fight poverty. An example of such involvement is the presentation in 2016 of a Popular Legislative Initiative, backed by 700000 signatures, aimed at establishing a lump-sum basic income that would improve the lives of people without income and resources. ${ }^{6}$

Regarding income inequality, according to the canonical model of inequality and growth developed by Simon Kuznets in 1955, in which higher-income countries have lower inequality and, for already developed countries, inequality is expected to decrease with economic growth, we should expect that the process of economic convergence also leads to convergence in income inequality.

Does the Spanish experience of the past 35 years conform to the Kuznets pattern? Figure 11.5a reproduces the relationship between per capita GDP (in 2010 constant US\$) and the Gini coefficient from 1980 to 2016.7 A type of inverted U function can be adjusted to the data, although only with some imagination and the help of statistical analysis tools. The slope of the decreasing part of the curve is quite low, pointing to a meagre equalising effect of per capita GDP growth in Spain. More revealing is the analysis of the second part of the series, corresponding to the period 2004-16 (Figure $11.5 \mathrm{~b}$ ), where the inequality-exacerbating impact of the crisis is clear. Also clear is the different path followed with economic recovery in 2014, with inequality almost stagnant.

When we look at income inequality in Spain from a comparative European perspective (Figure 11.6) we observe the following: (1) higher than average inequality compared with the EU27 and, especially with the countries with lower inequality in each of the years of the series; (2) convergence in the first part of the series (1997-2001) and divergence afterwards, for 2004 onwards, even before the start of the crisis; (3) an increase in inequality in those countries with a lower Gini index; and (4) at the end of the period, the Spanish Gini index was around 12 per cent higher than the average and almost one-third higher than the country with the lowest income inequality.

At this stage of the analysis we would like to draw attention to two elements underlying the size and trend of income inequality in Spain. The first is the relationship between income inequality and social expenditure. As is well known, social expenditure is a major element in the correction of income inequalities, both through fiscal policy (progressive taxation) and social expenditure (pensions and social assistance). When we look at income inequality in market income - that is, before taxes and transfers - Spain is located near the EU average, with lower income inequality than countries such as Sweden or Germany (Muñoz de Bustillo 2016). The Spanish peculiarity regarding income distribution in the EU context - its higher level of inequality - is not explained by the fact that Spain has the worst results in income distribution, but by the lower redistributive capacity of the Spanish welfare state. The lack of convergence in social protection expenditure also translates into lower convergence in income (in)equality. A similar connection can be drawn between higher income inequality and lower employment levels - especially since the Great Recession - as the massive levels of unemployment associated with the economic crisis are behind the increase in inequality over the past few years.

This conclusion is somehow buttressed by the existing information on wage inequality. From a European perspective Spain does not have a significantly higher level of wage inequality. In 2014 Spain and Italy were the only two countries from a sample of $23 \mathrm{EU}$ 

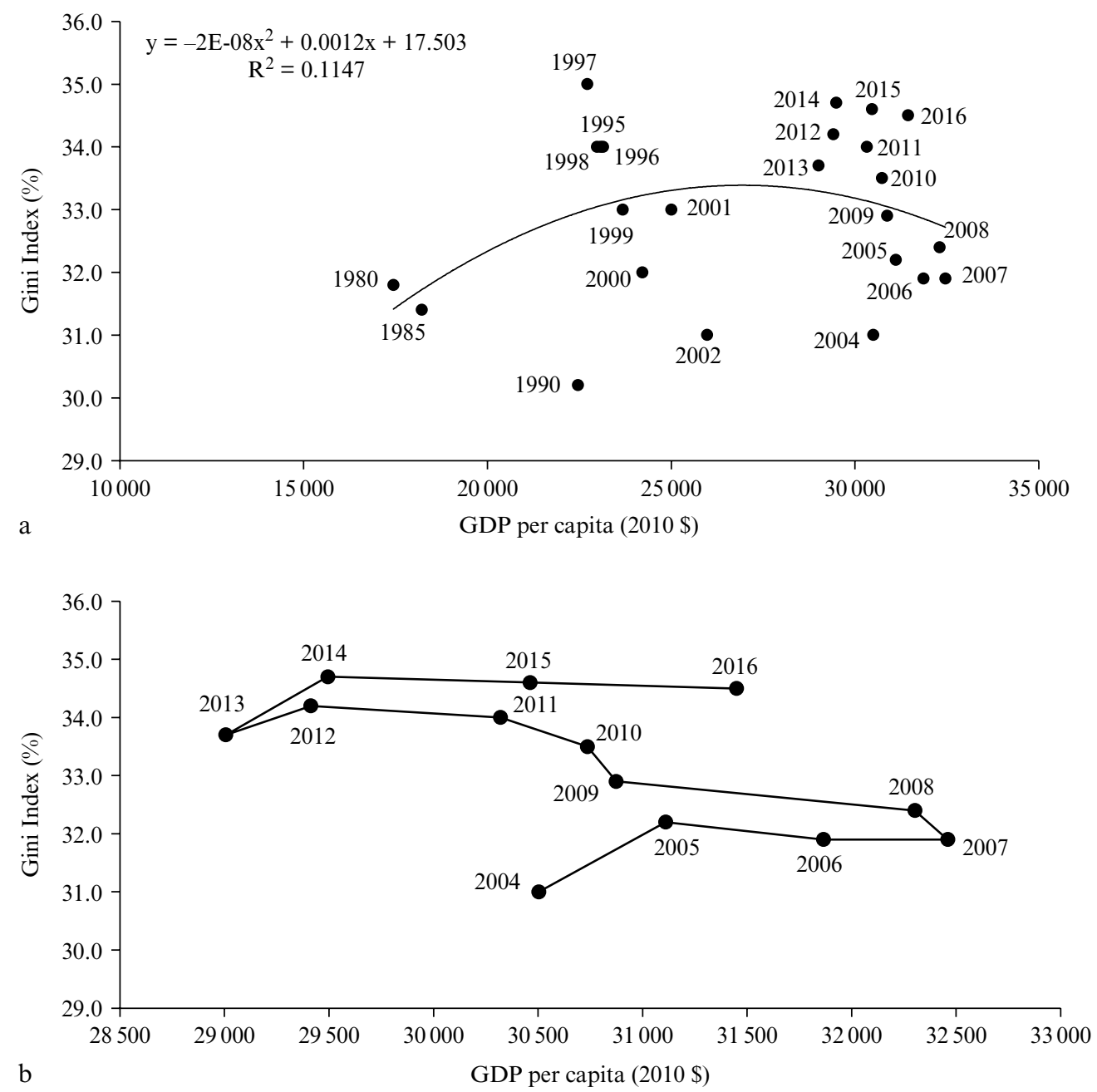

Source: Author's analysis from LIS, ECHP, SILC and World Development Indicators (WDI) (World Bank).

Figure 11.5 Income per capita and inequality, Spain, 1980-2016

countries with data on wage and income inequality in which higher-than-average income inequality was paired with lower-than-average wage inequality. Such a lower level of wage inequality is related to an industrial relations system in which the automatic extension of collective agreements warrants a high level of collective agreement coverage, even in a context of low trade union affiliation rates. As argued in OECD (2004) and Muñoz de Bustillo and Pinto (2017), collective agreement coverage has a major and inverse impact on wage inequality.

Complementing the information on the lack of convergence in income inequality, we now address the evolution of poverty rates in Spain vis-à-vis the EU. To this end, 


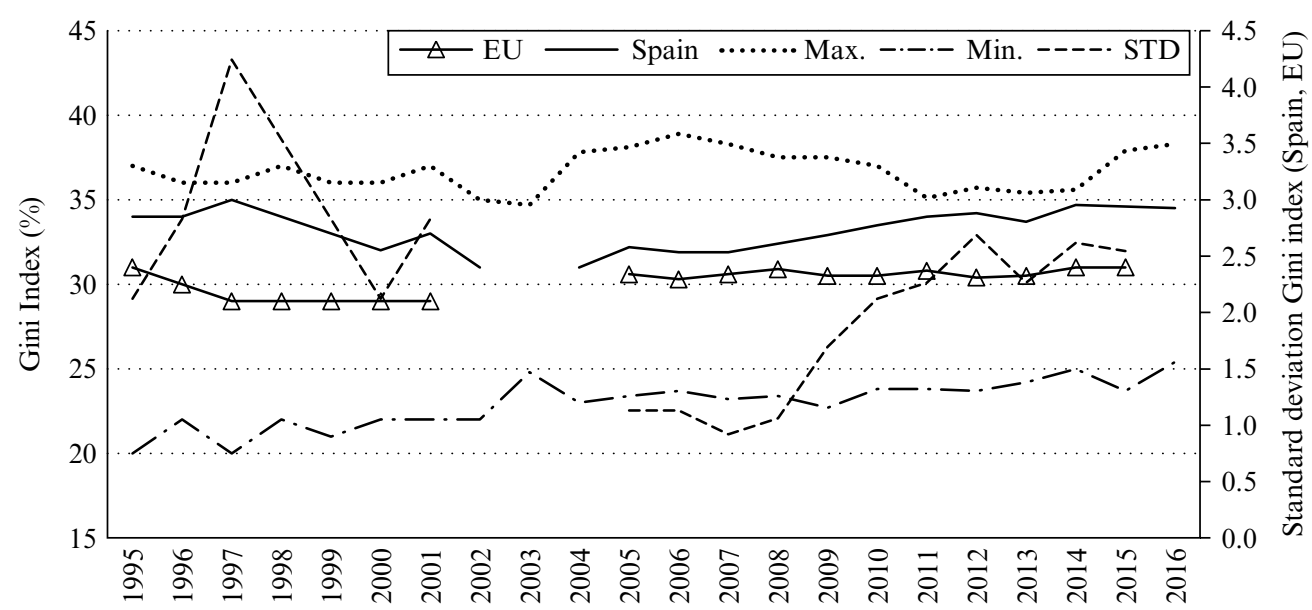

Source: Author's analysis from ECHP and SILC.

Figure 11.6 Income inequality in Spain, the EU27 and the most equal and unequal member states, 1995-2016 (Gini index and standard deviation)

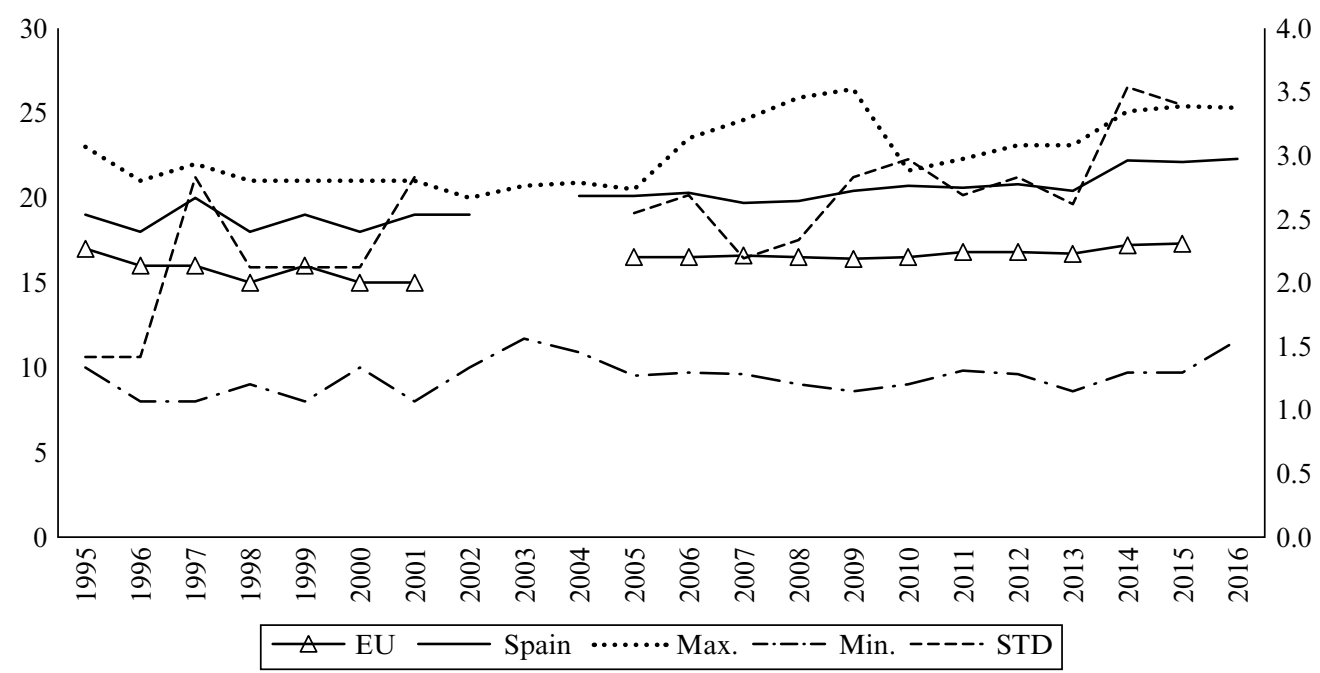

Source: Author's analysis from ECHP and SILC.

Figure 11.7 Poverty rates in Spain, the EU15 and most equal and unequal EU27 member states, 1995-2016 (Gini index and standard deviation)

Figure 11.7 reproduces the evolution of poverty rates in the past two decades in Spain, the EU15 and the EU27 countries with higher and lower poverty rates in each of the years considered. Figure 11.7 also includes the standard deviation of the Spanish and EU poverty rates as a summary index of convergence. The figure is clear: Spain had both 
higher and diverging rates of poverty compared with the EU, very similar to those of the countries with the highest poverty rates. ${ }^{8}$

To conclude this section we use one of the better known alternative indexes of wellbeing, the Index of Economic Well-Being (IEWB), developed by the Canadian Centre for the Study of Living Standards (Osberg and Sharpe 1998), to monitor the existence (or lack) of economic social convergence from an aggregate perspective. The IEWB is an aggregate index composed of four dimensions:

1. Effective per capita consumption flows, including consumption of marketed goods and services; government services; effective per capita flows of household production; leisure; and changes in life span.

2. Net societal accumulation of stocks of productive resources, including net accumulation of tangible capital; housing stocks; net changes in the value of natural resource stocks; environmental costs; net changes in the level of foreign indebtedness; accumulation of human capital; and stock of research and development (R\&D) investment.

3. Income distribution, including intensity of poverty (incidence and depth) and inequality of income.

4. Economic security from job loss and unemployment, illness, family breakup and poverty in old age (Osberg and Sharpe 2002, p. 295).

Each of the dimensions is composed of different subcomponents, making a total of 18 . The four dimensions have equal weighting.

This indicator offers a good opportunity to test whether, from a general perspective - a single index including the economic and social dimensions of well-being - there has been convergence between Spain and other European countries. To this end, we base our analysis on the data provided by Lars Osberg and Andrew Sharpe (2016) for a sample of high-income countries from 1980 to 2014. As these authors do not present data for country aggregates such as the EU, we have opted to compare the evolution of the IEWB with the simple average of the nine European countries with available data on their IEWB: Belgium, Denmark, Finland, France, Germany, Italy, Netherlands, Sweden and the United Kingdom. Figure 11.8 reproduces the evolution of the IEWB for Spain and the average of the aforementioned nine European countries, together with the now customary standard deviation of the two indexes, as a summary index of convergence.

The general picture presented by Figure 11.8 is fairly pessimistic regarding the convergence of well-being between Spain and the average of core European countries. Although convergence can be observed during the 1980s, the economic crisis of 1993 completely altered the picture, leading to a change in trend. With economic recovery after the crisis we observe a reduction of the differences in IEWB. Unfortunately, this convergence is short lived, as from 2000 the paths start diverging again. Such a divergence trend is highly intensified during the Great Recession as result of the fall of the Spanish IEWB against a stagnant, but not falling, average IEWB. Taking advantage of the tree-like construction of the IEWB, we can explore how the different components of the IEWB have fared in the period and their contribution to the increasing divergence. As we can see in Figure 11.9 - excluding the dimension of wealth stocks, which fully converges during the period thanks to the change in the intensity of convergence from 2000 onward - the other dimensions show divergence in relation to the nine European countries' average used as 


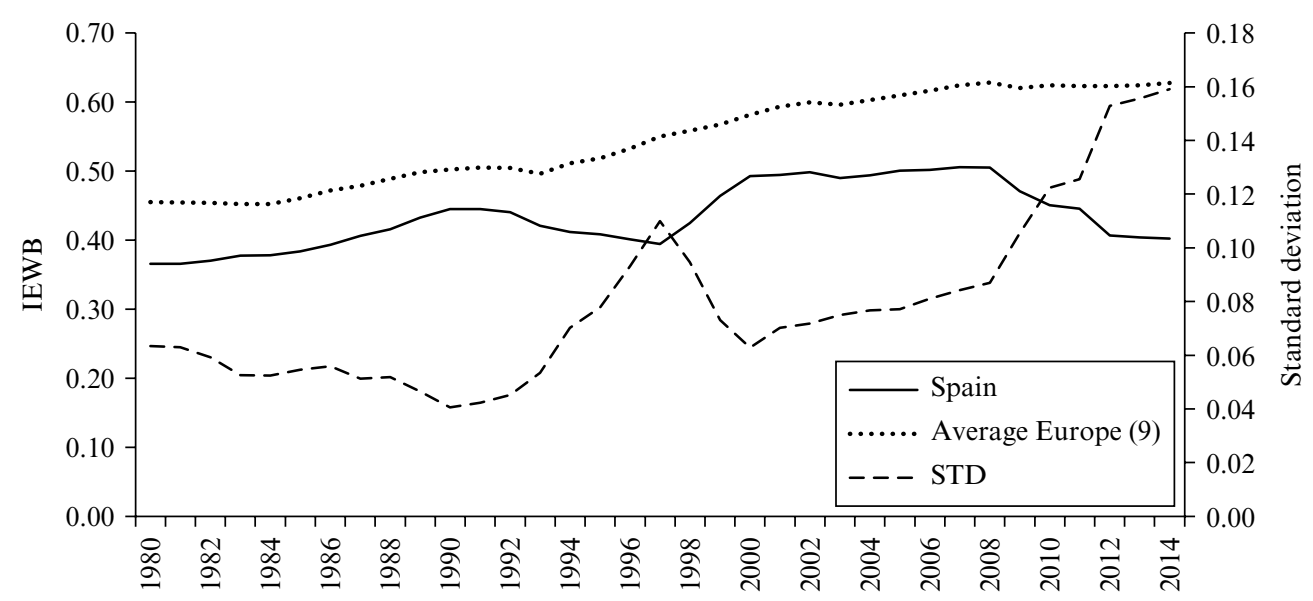

Note: * Belgium, Denmark, Finland, France, Germany, Italy, Netherlands, Spain, Sweden, UK.

Source: Author's analysis based on Osberg and Sharpe (2016).

Figure 11.8 Index of Economic Well-Being of Spain and average of nine European countries, * 1980-2014

a benchmark. In one of the dimensions, consumption flows, the process of convergence was frustrated by the 1993 crisis, after which Spain was not able to regain its pre-crisis impetus. In this context, the Great Recession produced a major downturn in the indicator that lasted until the end of the period considered. The behaviour of the economic security dimension is also clearly explained by whatever happens in the economy, with two major drawbacks related to both crises. Finally, the dimension of inequality shows a first phase of divergence related to the 1993 crisis, but also a second phase starting well before the Great Recession.

In summary, the goal of convergence between Spain and Europe (taking the EU15 average as benchmark) has proven elusive, in both economic and social convergence. From the former perspective, convergence was brutally halted by the Great Recession, which was much deeper and longer in Spain than in the rest of the EU. More worrisome is the lack of convergence from a social perspective, in both inequality and poverty rates. This lack of convergence, if not divergence, can be explained, among other factors, by the abnormally high unemployment rates experienced in Spain during much of the past four decades and to the existence of a weak welfare state with very little capacity (or will?) to reduce the inequalities generated by the market.

In this context, the social partners and the industrial relations system have contributed, as far as they were able, to economic and social convergence by facilitating wage moderation, while reducing wage inequality. The trade unions have also been behind some major improvements in social protection, such as the creation of non-contributory pensions. 

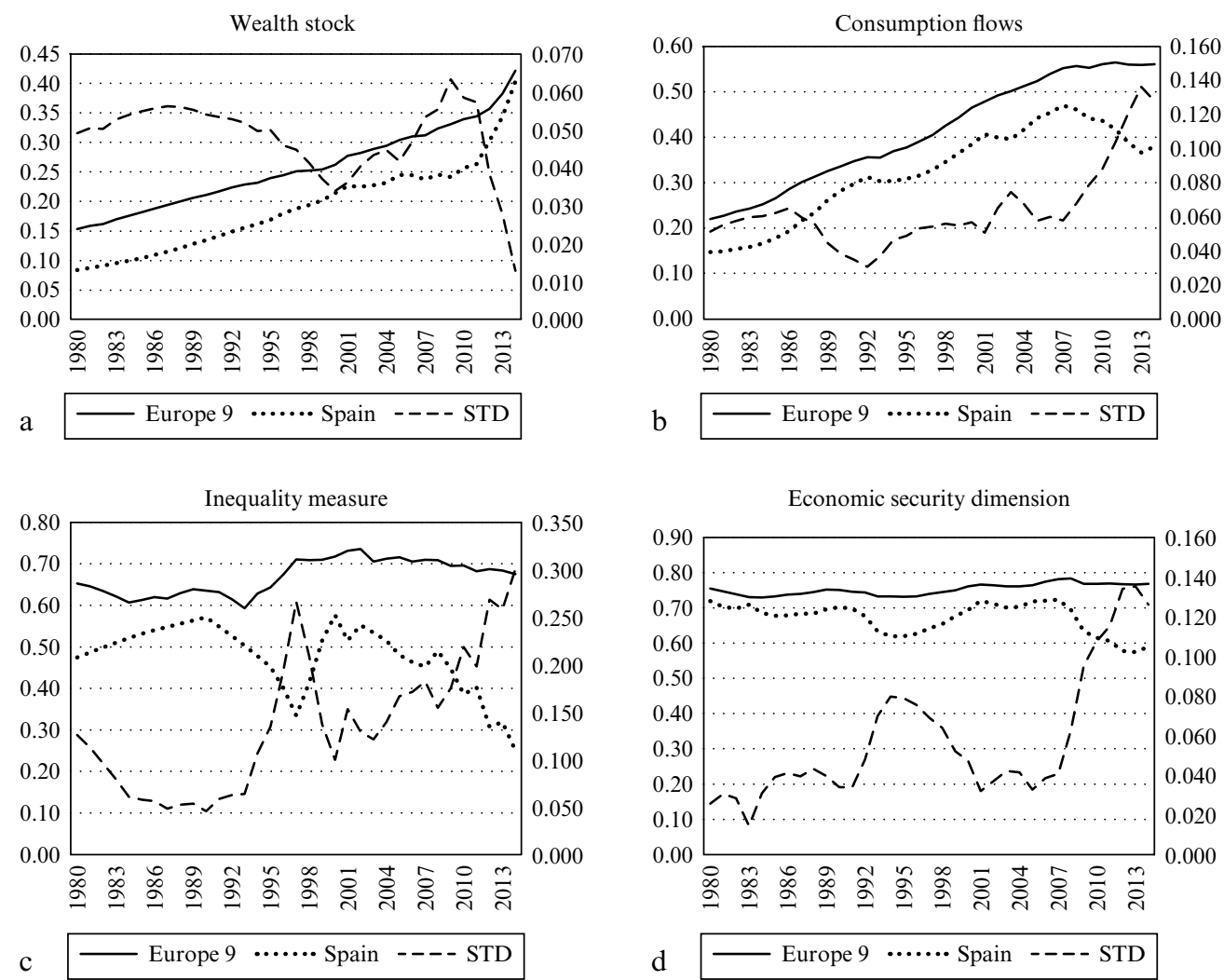

Source: Author's analysis based on Osberg and Sharpe (2016).

Figure 11.9 Dimensions of the Index of Economic Well-Being of Spain and the average of nine European countries, 1980-2013

\section{CONVERGENCE WITHIN SPAIN}

The existence of a single institutional framework for all the Spanish regions means that, from a legislative perspective - with some differences pertaining to financing and regulation at the regional level (Comunidades Autónomas) that can be sizeable - all residents of Spain have access to roughly similar public services. For that reason, we focus our analysis of convergence within Spain on just two variables: per capita income and unemployment.

Figure 11.10 presents the dispersion of regional income per capita in the long run (1955-2014) among the 17 Spanish autonomous regions. Again we use an indicator of absolute dispersion (standard deviation) and a relative indicator of dispersion (coefficient of variation). In relative terms there is a strong process of convergence among the Spanish regions until the late 1970 s, which petered out at the turn of the century. Behind this process of regional convergence we find strong movements of population from the 


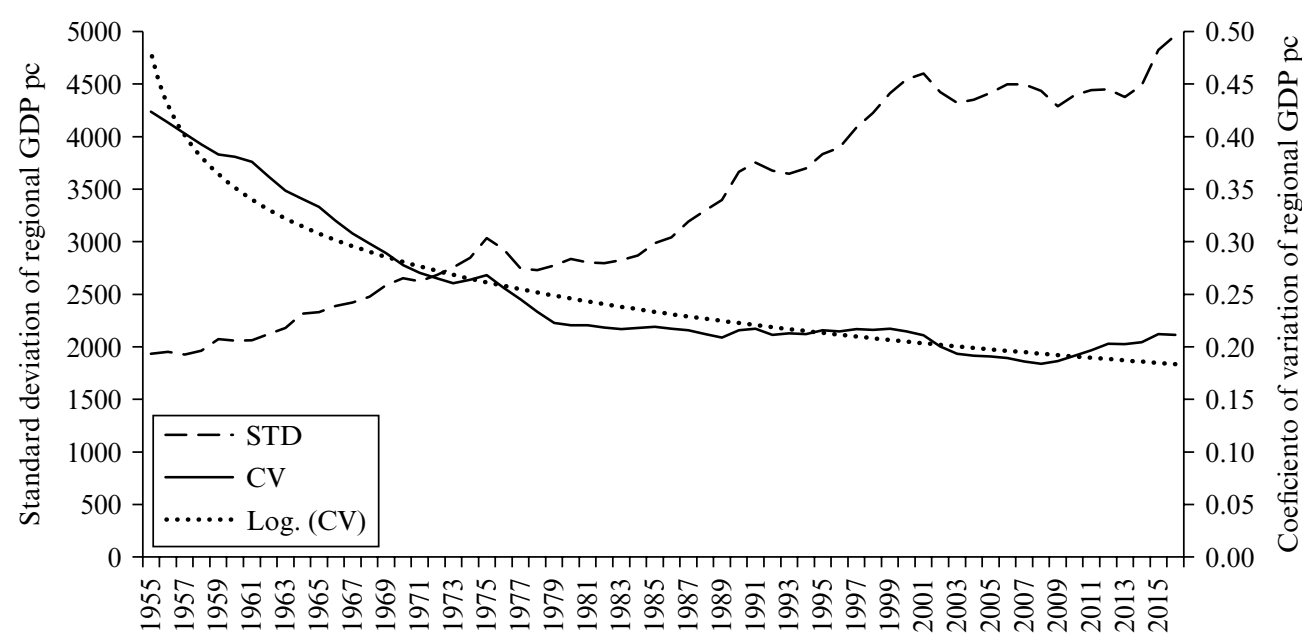

Source: Author's analysis based on De la Fuente (2016) and INE (Contabilidad Regional de España for 2015-16).

\section{Figure 11.10 GDP convergence among the Spanish regions, 1955-2015}

less developed to the more developed regions (Raymond and García Greciano 1996). This convergence is not intensive enough to reduce the differences in per capita GDP in absolute terms; from this last perspective, we can observe increasing differences until the turn of the century, when they stabilise until the crisis. For the last year of the series, the richest region (Madrid) has a per capita GDP roughly double that of the region with the lowest per capita GDP (Extremadura). Such differences in market terms are reduced by roughly one-fifth when measured in disposable income.

It is important to acknowledge that the dispersion of regional GDP in Spain is relatively low compared with most EU countries. In 2015, the coefficient of variation of per capita GDP of the Spanish regions, 0.21, put Spain at the lower end of the EU in regional per capita GDP dispersion, together with countries such as Greece, Finland and the United Kingdom (excluding inner London) or France, and with much lower values than countries such as Slovakia, on $0.67 .^{9}$ To put this in context, for the same year, the coefficient of variation of the per capita GDP of the EU member states was 0.43 , so the dispersion of regional per capita GDP in countries such as Spain or France is roughly half the dispersion between the per capita GDP of the EU member states.

Many factors underlie these differences in per capita GDP: paraphrasing Jeffrey Sachs (1997), from elements related to nature to elements related to nurture; from different economic structures leading to diverse productivity levels to different demographics. Among these items, we would like to call attention to one, the unemployment rate, which has a profound impact on both economic and social development and convergence. As Figure 11.11 shows (national average unemployment rate along with the unemployment rates of the region with the lowest and highest unemployment rates each quarter), not only is there a wide gap between such rates, but the dispersion has increased during the crisis, with the standard deviation growing by more than 50 per cent from 2008 to 2017 . 


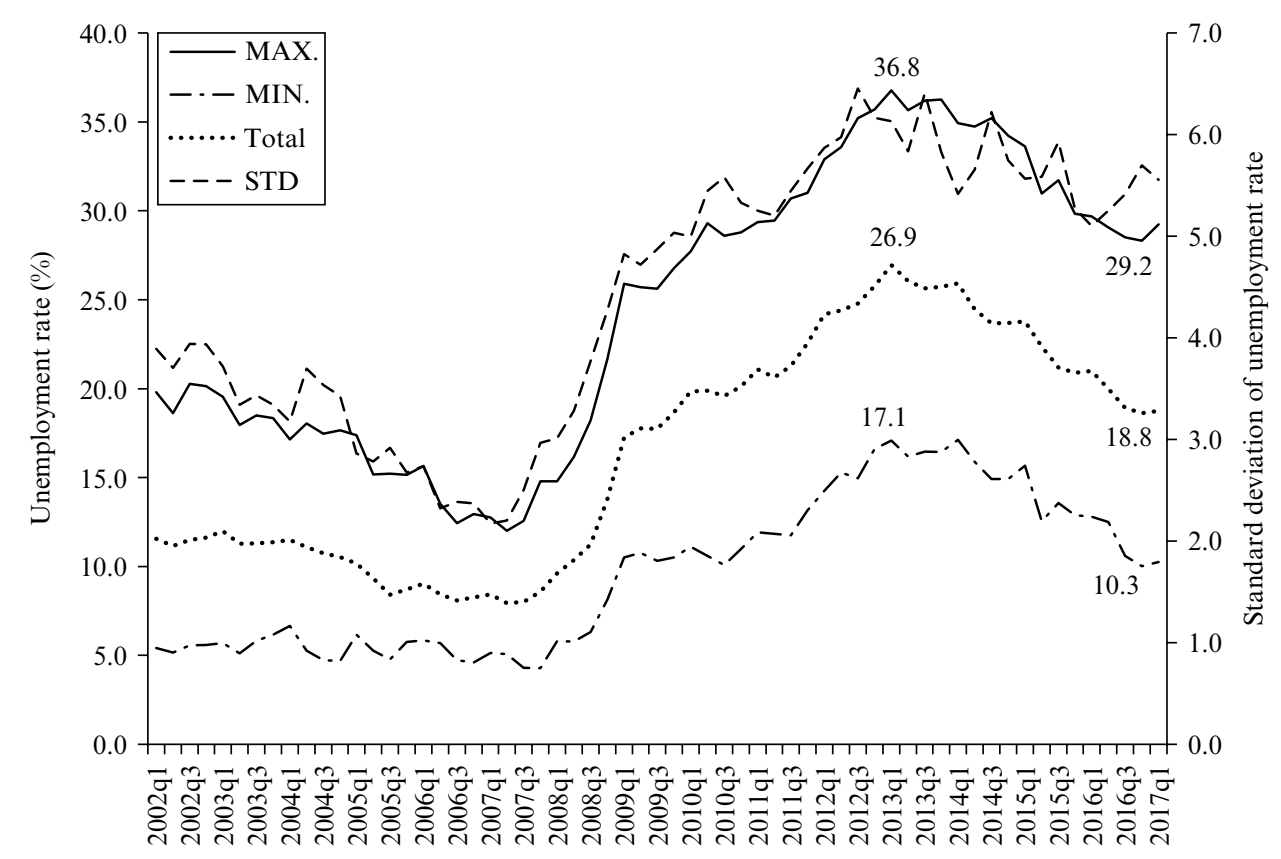

Source: Author's elaboration based on EPA.

Figure 11.11 Unemployment rate in the region with the highest and lowest unemployment rate, Spain, 2002-17

\section{INSTITUTIONAL CONVERGENCE}

Complementing the analysis developed above, in this section we approach the issue of convergence from a different perspective, focusing on institutions and policies. The task now is to review the extent to which Spanish socio-economic institutions have followed a path of convergence towards their European counterparts. Without doubt, one of the main accomplishments of the theory of economic development in recent decades has been the discovery of the major role played by institutions in the process of economic development. As stated by Dani Rodrik (2004, p. 10), 'There is now widespread agreement among economists studying economic growth that institutional quality holds the key to prevailing patterns of prosperity around the world'. Unfortunately, such agreement does not go as far as allowing us to present a fixed set of institutional arrangements conducive to economic growth, because, again in Rodrik's words (Rodrik and Subramanian 2003, p. 33), 'institutional solutions that perform well in one setting may be inappropriate in a setting without the supporting norms and complementary institutions. In other words, institutional innovations do not necessarily travel well'.

Owing to restrictions of space, it is not possible to present here a full account of the existence (or lack) of such processes of institutional convergence and their role in socio-economic convergence. As an alternative, we focus on three elements of the greatest 
importance for the proper working of the labour market and social cohesion: the minimum wage, unemployment benefits and non-standard employment relations.

\subsection{Minimum Wages}

According to Eurostat, in 2016 (last available information), the Spanish minimum wage was among the lowest (as a proportion of the mean value of average monthly earnings) of all EU countries with minimum wage systems: 34.1 per cent compared with a simple average of 43.3 per cent ( 21 countries). ${ }^{10}$ Furthermore, the gap between the Spanish minimum wage as a proportion of the average of the $21 \mathrm{EU}$ countries with available data doubled during the period 2008-15, going from -10 per cent to -20 per cent.

According to the Spanish Labour Code, the setting of the minimum wage is the competence of the government, after consultation with the social partners and taking into account the development of the price index, productivity, the share of wages in national income and the economic situation in general, but without the application of a specific algorithm. As a result, in practice, the setting of the minimum wage is often a unilateral government decision. ${ }^{11}$ As argued by Banyuls et al. (2011), in Spain the minimum wage has not been an important topic of social dialogue, as the trade unions have traditionally preferred the alternative provided by collective bargaining to set a sectoral wage floor (usually higher than the minimum wage). This, together with the high collective agreement coverage, explains the relatively low percentage of workers on the minimum wage (3.5 per cent according to social security data).

The particularly low level of the minimum wage in Spain (vis-à-vis its European counterparts) led the major trade union federations (the General Union of Workers, UGT, and the Trade Union Confederation of Workers' Committees, CCOO) to demand - unsuccessfully - a monthly minimum wage of $€ 800$ for 2017 (compared with the actual minimum wage of $€ 707.7 \times 14$ monthly payments), aiming at a minimum wage of $€ 1000$ for 2020 in order to achieve the 50-60 per cent threshold proposed by the 1961 European Social Charter of the Council of Europe. After negotiations with the government, in December 2017 the social partners agreed to a minimum wage increase of 4 per cent for 2018, based on the compromise of achieving $€ 850$ (14 monthly payments) by 2020 . If this compromise is finally met (the agreement is subject to two conditions: annual GDP growth over 2.5 per cent and an increase of more than 450000 persons per year claiming social security benefits), the goal of a minimum wage of $€ 1000$ per month would be achieved by 2020. After an unexpected change in government in June 2018, in 2019 the minimum wage was increased by $22.3 \%$ by a minority government of the Spanish Socialist Party with the backing of Podemos, improving this situation.

The relatively high dispersion of minimum wages in the EU is related to the coexistence of different approaches. In some countries, such as Austria, Italy, Denmark, Finland and Sweden, minimum wages are set by collective agreements, while in others, such as France, the Netherlands, Spain, the United Kingdom and, more recently (2015), Germany, minimum wages are set by statutory regulations. As argued by Fernández-Macías and Vacas-Soriano (2016), such institutional diversity makes it more difficult, although not impossible, to advance towards coordination of minimum wages at the EU level. One option considered in the literature (Schulten 2008) is the use of the open method of coordination to set a common target level (related to the average national wage), leaving 
it up to the different member states to select the institutional mechanism to be used to achieve such an outcome.

\subsection{Unemployment Benefits}

In a country with a high unemployment rate across the cycle, unemployment benefits are a major source of social protection and social cohesion. As mentioned in the previous section, unemployment benefit is one of the two items of social policy on which social expenditure as a share of GDP is higher in Spain than the EU average. Unemployment benefit has also been singled out as one policy that could be mutualised in order to develop an instrument to improve the architecture of EMU. According to many analysts, EMU - and more precisely the role given to restrictions on the capacity of member states to incur deficit expending, as well as the policy of fiscal consolidation pursued in times of crisis (Muñoz de Bustillo 2014) - has led to a reduction in member states' capacity to implement counter-cyclical policies by means of deficit spending. One way to alleviate such a restriction would be to develop a European Unemployment Benefit Scheme that, under specific circumstances, would finance unemployment benefits by the EU (Beblavý et al. 2015). One of the difficulties faced to the establishment of such a scheme is the diverse nature of EU unemployment benefits. Unemployment benefits differ among EU member states in three different dimensions: (1) replacement rate, understood as a percentage of the previous wage; (2) duration; and (3) eligibility. These differences are magnified as replacement rates might be subject to maximum and minimum limits, differences related to family composition, duration of unemployment (usually related to decline in replacement rates), existence of unemployment assistance after the exhaustion of unemployment benefits, and so on. Furthermore, unemployment benefits might be complemented by other types of social benefit, such as housing allowance, with substantial implications in replacement rates in some countries, such as the United Kingdom. Table 11.2 presents the wide variation of unemployment benefit models with examples of countries with high and low unemployment benefit levels along the above-mentioned axis.

This diversity of unemployment benefit schemes implies that it is not easy to evaluate their convergence (or the lack of it) in the EU member states. If we look at a specific group of workers, for example, net replacement rates for single earners, whose previous in work earnings amounted to 67 per cent of average wages; from 2001 to 2015 no major overall changes can be detected in replacement rates in the EU and such changes do not follow a single pattern. A relatively small number of countries - such as Italy, Hungary, Belgium, Ireland and the Czech Republic - increased their replacement rates during the period by a sizeable percentage (from 14 per cent in the case of Belgium to 41 per cent in the case of Italy), while in a few others, such as Sweden and Romania, replacement rates decreased. The dispersion of replacement rates for this group of workers did not change much during the period, with a reduction in the standard deviation of 5.5 per cent. ${ }^{12}$

\subsection{Non-standard Forms of Employment}

During the Golden Age of capitalism (Marglin and Schor 1990), although there were a range of forms of employment, full-time open-ended employment was understood as the 
Table 11.2 Characteristics of unemployment benefits schemes, EU member states

\begin{tabular}{|c|c|c|c|}
\hline Axis & & $\begin{array}{l}\text { Countries at the lower } \\
\text { end }\end{array}$ & $\begin{array}{l}\text { Countries at the higher } \\
\text { end }\end{array}$ \\
\hline \multirow[t]{3}{*}{$\begin{array}{l}\text { Net replacement } \\
\text { rate }^{\mathrm{a}}\end{array}$} & $\begin{array}{r}\text { Single earner } 67 \% \\
\text { of average wage }\end{array}$ & $\begin{array}{l}\mathrm{UK}=20 \% \\
\text { Greece }=39 \% \\
\text { Lithuania }=41 \% \\
\text { Malta }=42 \%\end{array}$ & $\begin{array}{l}\text { Belgium }=88 \% \\
\text { Slovenia }=86 \% \\
\text { Denmark, } \\
\quad \text { Luxembourg }=84 \% \\
\text { Latvia }=83 \%\end{array}$ \\
\hline & $\begin{array}{l}\text { One earner married } \\
\text { couple } 100 \% \text { of } \\
\text { average wage }\end{array}$ & $\begin{array}{l}\mathrm{UK}=22 \% \\
\text { Greece }=29 \% \\
\text { Poland }=35 \\
\text { Romania }=32 \%\end{array}$ & $\begin{array}{l}\text { Luxembourg }=83 \% \\
\text { Latvia }=79 \% \\
\text { Portugal }=75 \% \\
\text { Italy }=69 \%\end{array}$ \\
\hline & $\begin{array}{l}\text { Single earner } 150 \% \\
\text { of average wage }\end{array}$ & $\begin{array}{l}\text { UK }=10 \% \\
\text { Greece }=21 \% \\
\text { Malta }=20 \% \\
\text { Romania, Ireland }=26 \%\end{array}$ & $\begin{array}{l}\text { Latvia }=85 \% \\
\text { Bulgaria }=77 \% \\
\text { Luxembourg }=75 \% \\
\text { France }=69 \%\end{array}$ \\
\hline Duration (months) ${ }^{\mathrm{b}}$ & & $\begin{array}{l}\text { Czech Republic }=5 \\
\text { UK, Slovakia }=6 \\
\text { Italy }=8 \\
\text { Austria }=9\end{array}$ & $\begin{array}{l}\text { Belgium }=60 \\
\text { Portugal }=27.6 \\
\text { France, Denmark }=24 \\
\text { Spain }=23.7\end{array}$ \\
\hline $\begin{array}{l}\text { Eligibilityc }^{c} \\
\text { Scale from } 1 \text { (least } \\
\text { strict) to } 5 \text { (most } \\
\text { strict) }\end{array}$ & & $\begin{array}{l}\text { Spain, Greece }=4 \\
\text { Portugal, Romania }=4.5 \\
\text { Italy }=4.5\end{array}$ & $\begin{array}{l}\text { Denmark, Cyprus, } \\
\quad \text { Czech Republic }=2 \\
\text { Finland, UK }=2.5 \\
\text { Belgium, France }=3\end{array}$ \\
\hline
\end{tabular}

Notes:

(a) Family does not qualify for cash housing assistance or social assistance 'top ups'. Spain 78 per cent, 54 per cent and 38 per cent, respectively.

(b) Unemployment benefit duration if 22 years of contributions, 2010.

(c) 2011.

Sources: (a) OECD Tax-benefit models 2015; (b) Stovicek and Turrini (2012, p. 23); (c) Stovicek and Turrini (2012, p. 23).

norm or standard way to organise the employment relationship for most workers and firms. The economic crisis of 1973 that ended these golden years was also the starting point of the development of new forms of employment relations, characterised by lower levels of employment security and higher uncertainty. With different timings, incidence and specificities, depending on the national institutional setting, these new forms of employment (often old forms recycled for the new times, old wine in new bottles) gained momentum in the late 1990s, as labour market flexibility came to be considered the cornerstone of the new global capitalism. In 1994 the OECD, in its influential Jobs Study, included among the policies proposed to fight unemployment an increase in working-time flexibility, especially through part-time work, and the reform of employment provisions by loosening mandatory restrictions on dismissals and permitting fixed-term contracts. The study also recommended policies to encourage entrepreneurship. Although the narrative of flexibilisation of labour markets was often accompanied by a parallel narrative of increasing security - flexisecurity - so that flexible labour markets could not be 
established at the price of higher worker insecurity, all too often the real emphasis was on the first part of the equation. The Jobs Study itself included among its recommendations a reform of unemployment insurance to limit the disincentive effects of the system, ${ }^{13} \mathrm{a}$ proposal often at odds with a policy of increasing security for workers in an increasingly flexible labour market.

The process of labour market deregulation fed by studies such as the Jobs Project led to the growth of non-standard employment across Europe, although at very different speeds. Spain has the doubtful honour of being the first country to liberalise temporary employment (in 1984). After the reform, fixed-term employment became the default entry-level contract in Spain. This dynamic led to an unparalleled growth of temporary employment that spread to one-third of all employees in less than a decade. Since then, other countries have followed, although at a slower pace, in what can be considered a process of (negative) convergence: convergence towards lower job quality.

To test the extent to which there is a trend toward higher levels of non-standard employment in the EU, we constructed an indicator of non-standard employment relations (NSER) defined as the share in total employment of temporary employment, involuntary part-time employment and solo self-employment (self-employed persons without employees or own-account workers). Figure 11.12 reproduces the evolution of NSER in the Big Five plus Sweden, as well as the standard deviation of the NSER rate. There has been convergence in the destandardisation of employment relations across the sample countries. This process is also extendable, although for a shorter period of time owing to lack of data, to the EU15 and the EU28.

Two caveats are worth mentioning as regards Figure 11.12. The first is that, owing to the use of a homogeneous definition of NSER for measurement purposes, in some countries we have left out country-specific NSER that could be of relevance for that country. That is the case, for example, for employees with zero-hour contracts in the United Kingdom. ${ }^{14}$ For this, it is important to acknowledge that features of the standard employment relationship might also differ in different countries. For example, openended contracts in, for example, France or Germany, enjoy a higher level of employment protection than in the United Kingdom. The second element to take into consideration is the existence of different combinations of non-standard forms of employment in the different countries of the sample. It is also important to highlight how the combination of the different forms of NSER has changed over time. In the Spanish case, for example, we can see a reduction in the share of temporary employment and solo self-employment (the former is related to the high rate of destruction of fixed-term jobs during the Great Recession) and an increase in involuntary part-time employment since the beginning of the crisis.

Although both the causes and drivers of non-standard employment relations are different among the member states, one element that seems to underlie their development across the EU is the level of unemployment. In Figure 11.13 there is a close connection between the rate of unemployment and the NSER rate $\left(\mathrm{R}^{2}\right.$ of 0.34$)$, which grows in intensity when we focus on the EU15 ( $\mathrm{R}^{2}$ of 0.62$)$. This relationship corresponds to two different elements. In the first, governments often, when facing high levels of unemployment, develop measures to increase labour market flexibility (whose absence is considered by mainstream labour economics to be a major cause of unemployment) by deregulating labour markets and allowing for the development of different types of non-standard 


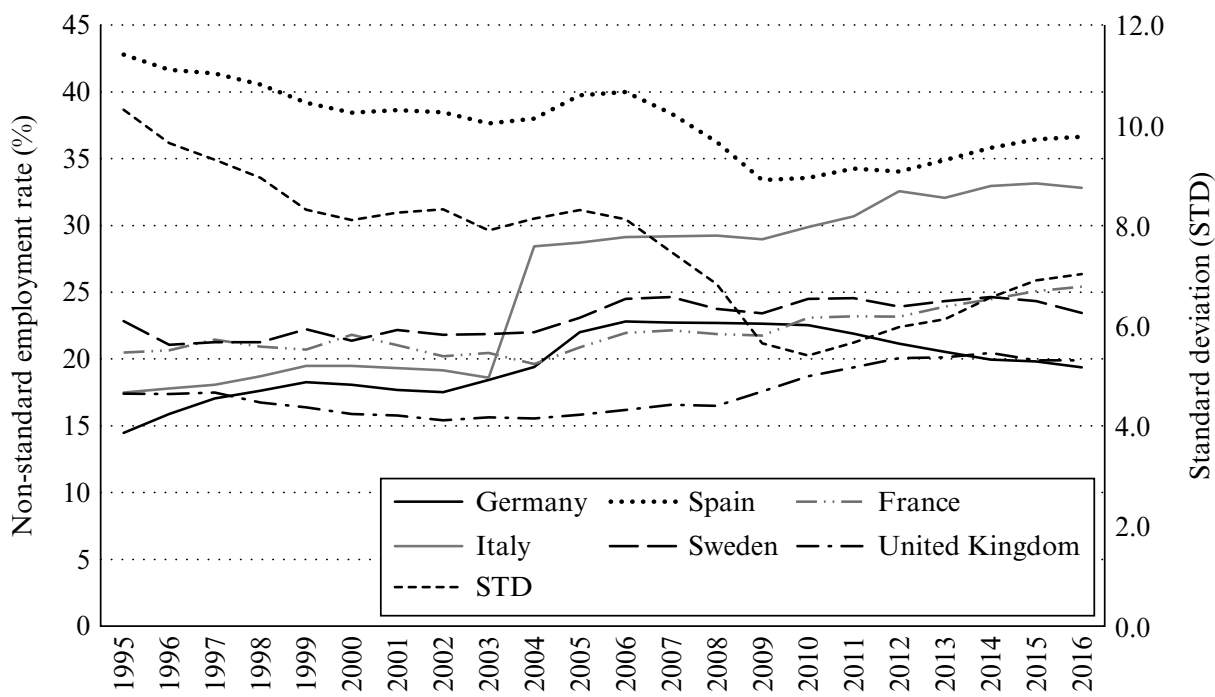

Source: Author's analysis based on EU Labour Force Survey (EU-LFS) data.

Figure 11.12 Evolution of non-standard employment in Germany, Italy, Spain, France, United Kingdom and Sweden, 1995-2016 (percentage of total employment)

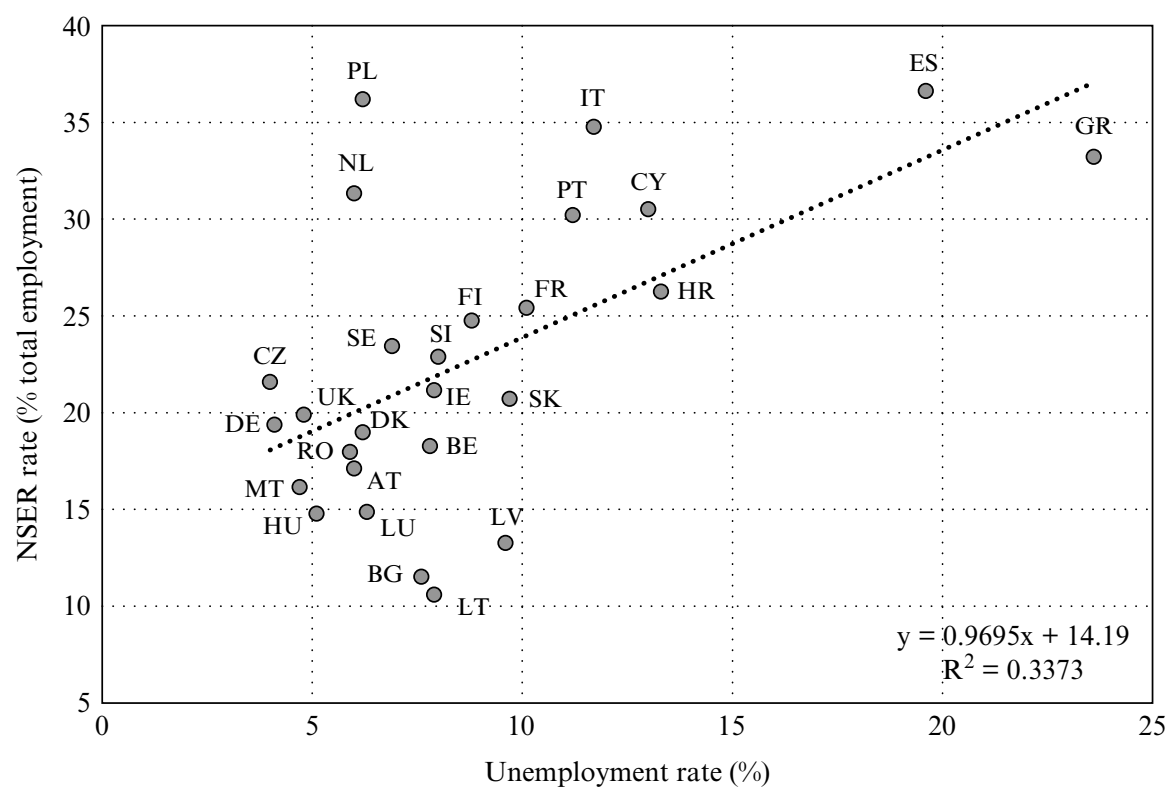

Source: Authors analysis based on EU-LFS data.

Figure 11.13 Unemployment rate and non-standard employment rate, EU, 2016 
employment. In the second, unemployment reduces both the power of trade unions to oppose such policies and the capacity of workers to reject such jobs.

As argued elsewhere (Muñoz de Bustillo and Pinto 2017), Spain's high level of NSER, fuelled by unparalleled levels of temporary employment (at least before the correction produced during the crisis) shows that the Spanish industrial relations system does not seem well suited to addressing this issue. Although some collective agreements address issues related to temporary employment, in 2015 these were a minority in both collective agreements and employees covered. For example, only 21 per cent of employees with a higher than firm-level collective agreement for which we have qualitative substantive information were protected by limits to the maximum number of temporary contracts ( 7.4 per cent in the case of firm-level agreements), and only 7 per cent ( 3.2 per cent in the case of firm-level agreements) had collective agreements that established limits to the index of employees with temporary contracts/total number of employees. Although trade unions have long pursued the reduction of temporary employment as one of their main goals, ${ }^{15}$ they have clearly failed. Among the reasons for such failure we can speculate on the following: the refusal of employers' associations to discuss an item that they consider part of their prerogative with regard to organising the production process, and the reluctance of trade unions to relate the reduction of temporary employment to a deterioration of open-ended contracts.

The three elements covered in this section are good examples of the difficulties involved in advancing towards common institutions (minimum wages and unemployment benefits), and how sometimes institutional convergence, as in the case of labour market flexibilisation, might lead to undesired effects in falling labour standards.

\section{CASE STUDY: CONVERGENCE IN IMMIGRATION RATES}

One of the areas in which Spain has experienced full convergence with the EU15 in little more than a decade is immigration rates. When Spain joined the EU, immigration was almost unknown. Not so long ago Spain was known as a country of emigration with important contingents of its population in both Latin America and the rest of Europe. With the exception of some agricultural areas, where immigrants were an important part of the labour landscape, in the rest of the country immigrants were an oddity. The situation remained largely unchanged for another decade after joining the EU, until suddenly, in the late 1990s, in a little less than a decade, Spain joined the group of countries with large immigrant populations. Such convergence is clearly shown in Figure 11.14, which reproduces the simple average of immigration rates in the EU14, the country with the highest and lowest immigration rate in the sample and the Spanish immigration rate. To facilitate reading the graph (and not distort the average) Luxembourg has been excluded from the figure (in 2015 Luxembourg had an immigration rate of 44 per cent). As we can see, starting from a very low rate in 1990 - among the lowest in the EU15 - the immigration rate skyrocketed in the first decade of the twenty-first century, surpassing the EU14 average. The Great Recession produced a reduction in the immigration rate, but it remained above the EU14 average in 2015.

In this journey Spain was accompanied by other EU countries, such as Ireland and Greece, which followed a similar pattern (Muñoz de Bustillo and Antón 2010). We can see in Figure 11.15 that over the past quarter century there has been convergence in 


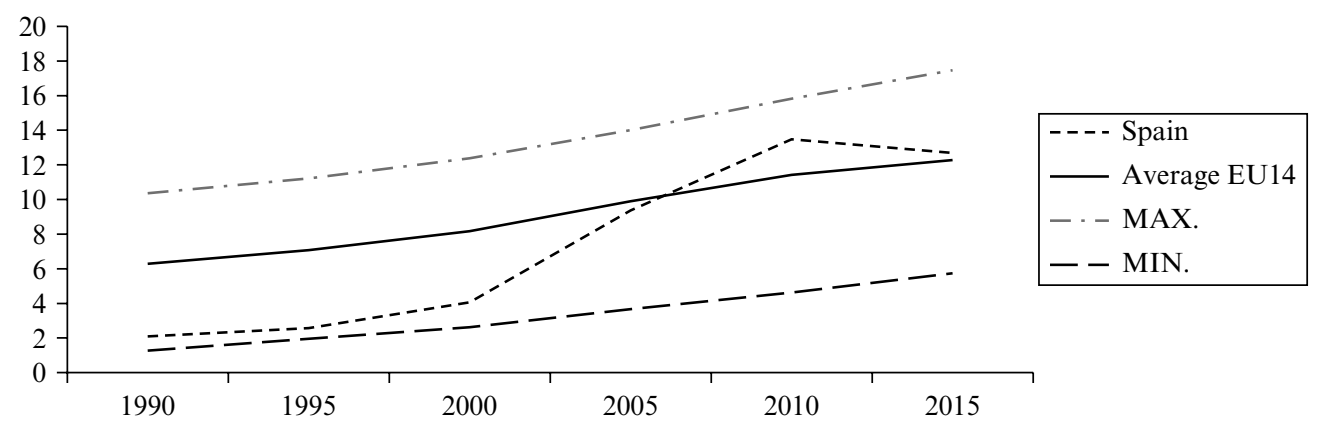

Source: Authors analysis based on UN (2015) data.

Figure 11.14 Immigration rates in Spain, the EU14 and countries with the minimum and maximum immigration rates, 1990-2015

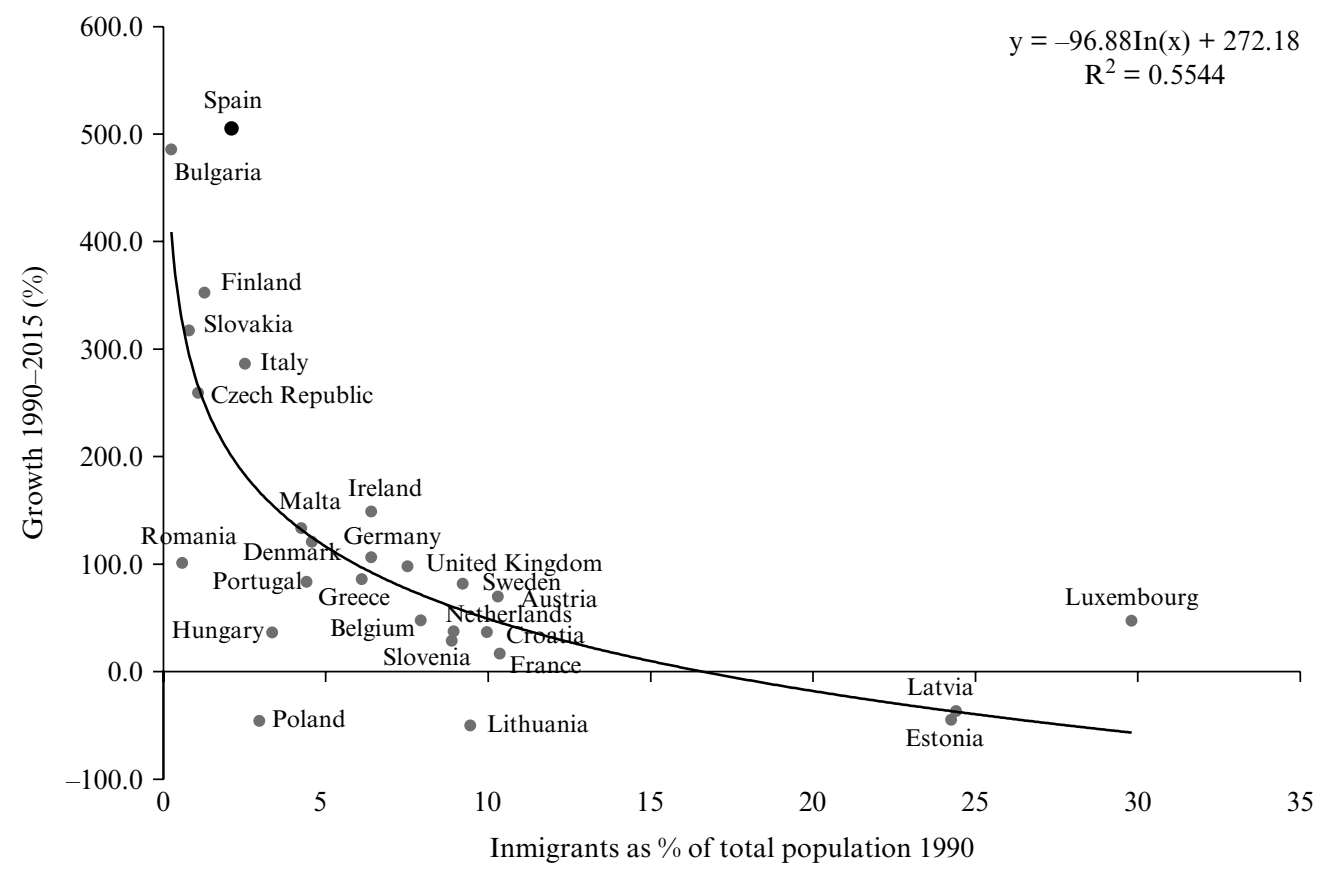

Source: Authors analysis based on UN (2015) data.

Figure 11.15 Immigration rate in 1990 and growth in immigration rates in the EU, 1990-2015 
immigration rates in the EU, as those members with lower immigration rates experienced higher growth in that respect than did those with high rates at the beginning of the period.

This process of massive immigration coincided with a relatively high (but decreasing) unemployment rate. Although immigration was omnipresent in the media and political discourse, and high on the list of concerns of the Spanish population, the integration of immigrants was successful in the sense that there was relatively little social conflict.

This is certainly not reflected in a high tolerance towards immigrants on the part of a majority of the population in comparison with other European countries. When asked whether there were already too many immigrants in the country or about their impact on the labour market, the responses were not particularly friendly. Regarding the first question, in 2008, just before the start of the Great Recession, 46 per cent of Spaniards considered that the number of immigrants in Spain was excessive (against 18 per cent who thought it was acceptable). ${ }^{16}$ The same year the percentage of Spanish citizens aged 15-29 years old who considered that immigrants took away jobs from Spaniards reached 51 per cent, while 68 per cent believed that immigrants exerted a downward pressure on wages (compared with 38 per cent and 50 per cent in 2002). ${ }^{17}$

In this context it is amazing that the Great Recession and its impact on the unemployment rate - which reached 26 per cent in 2013 - did not fuel major hostility against immigration at the political or street level. In Spain the type of political parties with radical (antipathetic) views on immigration (if not outright xenophobia) that have flourished in many other European countries - such as Germany, France, the Netherlands or Austria - have been absent from the political arena until late 2018, when one such party, Vox, won $12 \%$ of the votes in the in the Andalucian Parlamentary Elections.

One of the elements that could underlie the relatively peaceful integration of immigrants in the labour market is their high level of segregation in jobs, as immigrants and locals often work in different places, doing different things. In this regard, after Luxembourg, Greece and Cyprus, Spain is the EU country with the highest occupational segregation of immigrants as measured by the Duncan Index (Muñoz de Bustillo and Antón 2012). From a different perspective, it could be argued that the social partners, especially the trade unions, who embraced from the beginning the integration of immigrants in a context of equal treatment, have contributed to this peaceful coexistence. This position is especially praiseworthy when viewed against a public opinion that is not favourable to immigration.

According to the analysis of Penninx and Roosblad (2000), trade union attitudes to immigration can be explained by four factors: (1) their power in society and socioeconomic decision-making, (2) economic and labour market conditions, (3) social trends: public discourse, institutional arrangements, legislation, and so on, and (4) characteristics of immigrants and public perceptions, related to degree of proximity to the immigrant population. Taking this list as a guide, we could say that the positive attitude of the trade unions regarding immigration was not what might have been expected: (1) even in the boom years prior to the crisis the unemployment rate was relatively high, (2) the dominant public discourse was critical of the huge increase in the immigrant population and (3) the public viewed immigration with growing concern. While at the beginning of the 2000s less than 10 per cent of the population were concerned about immigration, by September 2006 the figure had risen to almost 60 per cent. Interestingly, with the Great Recession the level of concern decreased to fewer than 5 per cent. Only the characteristics 
of the immigrant population favoured the trade unions' positive stance towards it, as an important majority of immigrants came from Latin America and shared the language and some cultural elements with locals.

As regards immigration, the major Spanish trade unions have been active on three different fronts. On the political front they have lobbied in favour of regularising irregular immigrants, bearing in mind that irregular immigration is the worst-case scenario, bad for the immigrant (bad working conditions and low wages), workers and firms (unfair competition), and the country as a whole (lower taxes). They have advocated a policy of taking a strong stance with employers who hire irregular workers and regularisation for immigrants. Since the 2000 reforms, trade unions have argued for a more generous immigration policy (Marino et al. 2015) but within the general framework of linking immigration policy to the needs of the labour market. Trade unions also participate in regional tripartite bodies, which are especially strong in agricultural areas, where immigration is an important feature of the labour market (Connolly et al. 2014), as well as in the Forum for Social Integration of Immigrants (FISI), a tripartite institution created in 1995 .

On the educational front, trade unions have played an important role in fighting xenophobia and discrimination in the workplace (Figure 11.16), backing the right of immigrants to participate in local and regional elections (Miravet 2008). However, according to Connolly et al. (2014), the dominant framing logic of trade union interventions in Spain has been class and social rights, with race and ethnicity a secondary concern.

Education federation of the UGT in favour of diversity at school: 'We are diversity'.

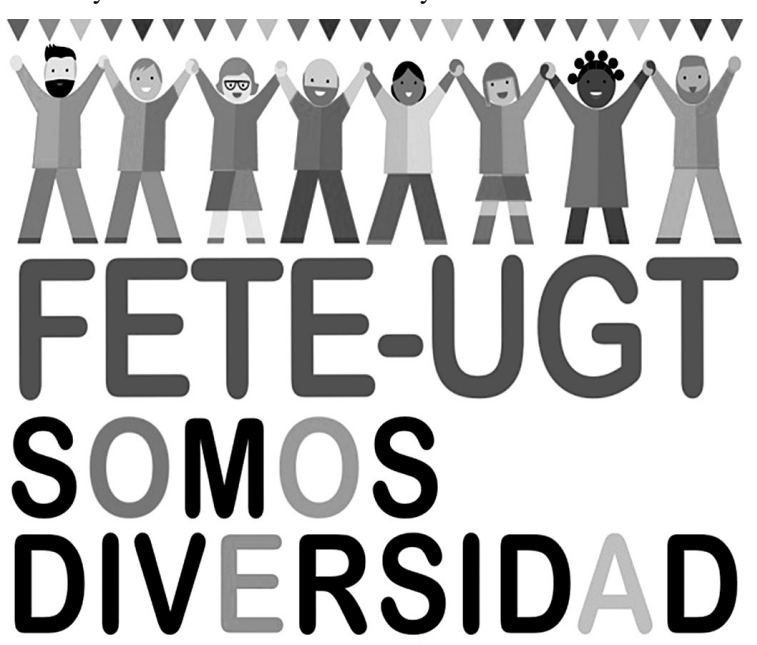

$\Delta \Delta \Delta \Delta \Delta \Delta \Delta \Delta \Delta \Delta \Delta \Delta \Delta \Delta \Delta \Delta \Delta \Delta \Delta \Delta \Delta \Delta$
Do you think discrimination at work is something that only happens to other types of people? Against discrimination, racism and xenophobia. Knowledge, solidarity and mutual respect.

¿CREES QUE LA DISCRIMINACIÓN EN

EL TRABAJO ES ALGO

QUE LE PASA SOLO A

CIERTAS PERSONAS?

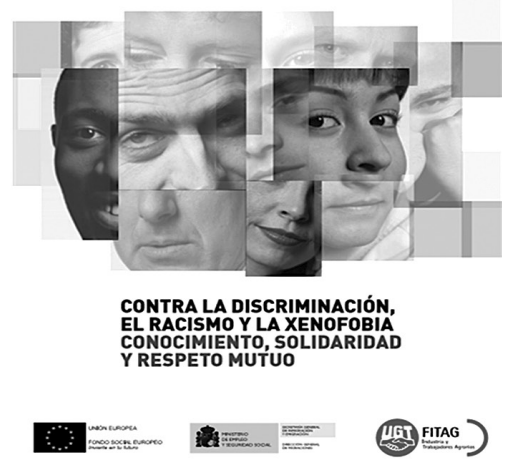

Source: UGT.

Figure 11.16 Two different campaigns against discrimination by UGT 
On the practical front, in collaboration with the Ministry of Employment and Social Affairs, for more than two decades trade unions have run the Centros de Información a Trabajadores Extranjeros (Information Centres for Foreign Workers, CITEs) aimed at counselling and providing information to immigrants on labour and legal immigration issues. For example, the CCOO has 136 CITEs throughout Spain.

The 'trade unions have not only acted in the organization of the defence and promotion of immigrants' rights and interests as workers but also as diversified instances of intervention in the process of integration and even as first stop in the process of insertion in the host country' (De Lucas et al. 2008, p. 131).

In this area the trade unions have worked side by side with employers' organisations in different tripartite forums dealing with immigration. For example, since its creation, the social partners have participated in the FISI. Among other inputs, the forum has lobbied in favour of smoothing out the renewal of temporary residence permits for immigrants made unemployed as a result of the Great Recession. The social partners have also been proactive in the provision of vocational training for immigrants in line with the needs of firms (both locally and in the sending countries) (Ramos 2014). The social partners also participate in the Tripartite Labour Commission for Immigration, which has a role in determining the list of occupations for which it is difficult to find workers, one of the tools used to manage immigration flows in Spain. ${ }^{18}$ The Spanish Economic and Social Council, a tripartite institution, and its 2004 report on 'Immigration and the labour market in Spain' played an important role in the last policy shift on immigration flows (the Royal Decree 2393/2004 of 30 December) (Stückow 2012).

\section{CONCLUSIONS}

We have reviewed Spain's economic and social convergence in recent decades, paying particular attention to the role of the industrial relations system developed during the economic and social transition years of the late 1970s and early 1980s. This has not been an easy task. Among the many roles played by industrial relation systems, promoting economic and social convergence is probably not a priority. Nevertheless, it can be argued that, by improving the working of the labour market, facilitating a stable and peaceful economic environment, creating a more favourable environment in the workplace, contributing to a fairer distribution of income and sufficient domestic demand, and promoting stable prices, industrial relation systems can contribute indirectly to the economic and social convergence of relatively laggard countries, such as Spain in the 1980s, towards others countries with higher economic and social standards. This instrumental perspective on the role of industrial relations is the perspective we have taken. In summary:

- The Spanish economy's impressive growth in per capita GDP was not enough to allow for full convergence with the leading countries of the EU. Moreover, this convergence was hampered by the Great Recession that took Spanish relative per capita GDP two decades back in time.

- From a longitudinal perspective, the Spanish economy shows two clearly differentiated drivers of convergence. The first, coinciding with the 1970s and 1980s, was based on productivity growth in a context of stagnant employment; the second, 
from the early 1990s until the start of the crisis, was based on employment growth with very moderate, or even stagnant productivity growth.

- Recent decades have witnessed convergence in labour force participation rates, closing the gap between Spain and the EU15, as well as in employment rates, although in the latter only until the start of the crisis. The crisis, again, dramatically changed the situation, leading to a growing gap that, at its highest, reached -15 per cent.

- Spanish trade unions played an important role in facilitating the economic and social transition to democracy in the late 1970s and early 1980s. To the extent that the success of this transition was necessary for continuing the process of convergence, we could say, loosely, that the industrial relations system played a functional role in such convergence.

- Social convergence, in relative resources allocated to social protection, was decoupled from the process of economic growth, as social expenditure as a share of GDP remained stagnant during more than a decade of high GDP and employment growth, leading to a weak welfare state. In this context of social expenditure stagnation, the trade unions contributed to some of the few improvements made in recent decades, such as the creation of a system of non-contributory universal pensions for retirees with no access to standard contributory retirement pensions in 1990, or, more recently, to the successful promotion during the crisis of the extension of unemployment assistance for the long-term unemployed without unemployment benefit protection.

- As regards income inequality, there has not been major convergence towards the EU average; on the contrary, income inequality measured by the Gini coefficient increased during the crisis, putting Spain among the most unequal EU member states. This lack of convergence is largely explained by, among other things, the lack of convergence in social expenditure (negatively correlated with income inequality) and by the lack of convergence in unemployment rates, especially during the crisis. In this context, the Spanish industrial relations system, with its wide collective agreement coverage, has played a mitigating role, contributing to comparatively low wage inequality.

- As regards convergence in socio-economic institutions, the three items reviewed in the chapter show how convergence has been elusive in minimum wages (an item excluded from social dialogue and set by the government) and unemployment benefits. In contrast, for non-standard employment relations, there has been convergence, but in this instance a convergence by the rest of the EU towards the Spanish abnormally early and abnormally high levels. This high level of nonstandard employment is particularly worrisome as some of the new developments associated with the digital economy, such as platform working, are especially well suited to the use of such employment. Thus we can envisage a future with a growing share of employees working under NSER.

- Our analysis of the intensive process of the convergence of Spain's immigration rates with those of the EU shows how the social partners can play an important role in facilitating the integration of immigrants in the host country.

In Spain the goal of convergence towards the rest of Europe (taking the EU15 average as benchmark) has to date proven elusive, from both an economic and a social 
perspective. In the former, convergence was abruptly halted by the Great Recession, which was much deeper and longer in Spain that in the rest of the EU. More worrisome is the lack of convergence from a social perspective, in both inequality and poverty rates. This lack of convergence, when not divergence, can be explained, among other factors, by the abnormally high unemployment rates experienced in Spain during much of the past four decades, and by the existence of a weak welfare state with very little capacity (or will?) to reduce the inequalities generated by the market.

\section{NOTES}

1. According to Eurobarometer, 62 per cent of Spaniards identify themselves as very or fairly pro-Europe, on a scale ranging from 30 per cent (Cyprus) to 82 per cent (Luxembourg) (Standard Eurobarometer 3 November 2016).

2. Differences in GDP per capita can be decomposed into differences in productivity and differences in employment rates.

3. The series was constructed by merging the 1850-1990 data of Bolt et al. (2014, p. 67; decennial data), with the GDP per capita data of the World Development Indicators Data Base (GDP per capita, PPP, constant 2011 international \$) of the World Bank, from 1990-2016 (annual data). For the purpose of this analysis it was considered sufficient to do the merging by scaling the 1990 numbers of Bolt et al. (2014) to the World Bank numbers and then rescaling the whole series until 1850.

4. An interesting approach to the pros and cons of wage moderation (or wage deflation) can be found in the analysis of the Spanish crisis by Álvarez et al. (2017), using the methodology proposed by Bhadhuri and Marglin (1990).

5. Unión General de Trabajadores y Comisiones Obreras (1990).

6. Proposición de Ley sobre establecimiento de una prestación de ingresos mínimos en el ámbito de protección de la Seguridad Social (Boletín Oficial de las Cortes Generales. Congreso de los Diputados, XII Legislatura. Serie B: Proposiciones de Ley, 9 de septiembre de 2016).

7. It is important to note that we are using three different sources of income distribution, Luxembourg Income Study (LIS) (1980-90), the European Community Household Panel (ECHP) (1995-2002) and Statistics on Income and Living Conditions (SILC) (2004-16), and even within a given source homogeneity is not guaranteed (in 2012 there was a major change in the method of gathering income data in SILC).

8. The index of poverty used by the EU is relative in nature, with the poverty threshold defined as 60 per cent of national median income. On this basis, in a context of decreasing income, such as the financial and economic crisis, the poverty threshold will also decrease year after year, affecting also the rate of poverty. When we correct this effect, anchoring the poverty threshold to 2008, the impact of the crisis on poverty rates is much more dramatic, especially in Spain, with the poverty rate rising from 20 to 31 per cent in 2014, and down slightly to 29 per cent in 2016. A similar rising pattern, but gentler, can be found for the EU27: from 16.5 per cent in 2008 to 19.5 per cent in 2014 (Eurostat).

9. Coefficient of variation of GDP per capita of NUTS 2 regions calculated from Eurostat (GDP at current market prices by Nomenclature of Territorial Units for Statistics (NUTS) 2 regions).

10. Belgium, France and Estonia, data corresponding to 2014 and 2015. Monthly minimum wage as a proportion of average monthly earnings (percentage); NACE Rev. 2. Industry, construction and services (except activities of households as employers and extra-territorial organisations and bodies).

11. A recent Decision by the Governing Body of the ILO (329th Session, Geneva, 9-24 March 2017, p. 91) stresses the importance of allowing the social partners to fully participate in the process of minimum wage setting: 'the Committee expects that in all processes for the determination of the SMI the Government will fully consult the representative organizations of employers and workers concerned, ensuring that they have full knowledge of all the necessary information and sufficient time to determine their positions' (ILO 2017, p. 12).

12. Author's analysis of OECD Tax-Benefit Models.

13. 'Countries should legislate for only moderate levels of benefit, maintain effective checks on eligibility, and guarantee places on active programs as a substitute for paying passive income support indefinitely' (OECD 1994, hypertext version: Part 3b, Policy Recommendations, point 9).

14. The latest estimate from the UK LFS shows that nearly 0.9 million people were on a 'zero-hours contract' in the second quarter of 2017, representing 2.8 per cent of total employment (Office for National Statistics).

15. To mention just one of their latest proposals, in May 2017 the UGT and the CCOO proposed to the gov- 
ernment, among other measures, that it increase social contributions for this kind of contract in order to disincentive its use by firms. In April 2017, both trade union federations had signed an agreement with the Ministry of the Treasury and Public Administration aimed at reducing the rate of temporary employment in public administration to 8 per cent over three years.

16. Interestingly, in 2015 the percentage was down to 28 per cent, precisely at a time of growing unemployment (Centro de Investigaciones Sociológicas, CIS, Estudio sobre la juventud en España 2008 (II), July, Estudio 2.767).

17. CIS E.4.02.01.011.

18. Real Decreto 557/2011, de 20 de abril, por el que se aprueba el Reglamento de la Ley Orgánica 4/2000, sobre derechos y libertades de los extranjeros en España y su integración social, tras su reforma por Ley Orgánica 2/2009.

\section{REFERENCES}

Álvarez, I., J. Uxó and E. Febrero (2017), 'Internal devaluation in a wage-led economy. The case of Spain', ICEI Working Paper No. WP05/17, Instituto Complutense de Estudios Internacionales, Somosaguas, Madrid.

Banco de España (2002), 'Informe Annual', Banco de España, Madrid.

Banyuls, J., E. Cano and E. Aguado (2011), 'La incidencia del salario mínimo interprofesional en sectores de bajos salarios', Cuadernos de Relaciones Laborales, 29 (2), 363-89.

Beblavý, M., G. Marconi and I. Maselli (2015), A European Unemployment Benefit Scheme: The Rationale and the Challenges Ahead, Brussels, Centre for European Policy Studies.

Bhaduri, A. and S. Marglin (1990), 'Unemployment and the real wage - the economic basis for contesting political ideologies', Cambridge Journal of Economics, 14 (4), 375-93.

Bolt, J., M. Timer and J.L. Van Zanden (2014), 'GDP per capita since 1820', in J.L. van Zanden, J. Baten, M. Mira d'Ercole, A. Rijpma, C. Smith and M. Timmer (eds), How Was Life? Global Well-being since 1820, Paris: OECD, pp. 57-100.

Connolly, H., M. Martinez Lucio and S. Marino (2014), 'Trade union renewal and the challenges of representation: strategies towards migrant and ethnic minority workers in the Netherlands, Spain and the United Kingdom', European Journal of Industrial Relations, 20 (1), 5-20.

De la Fuente, A. (2016), 'Series enlazadas de Contabilidad Regional para España, 1980-2014', Estudios sobre la Economía Española - 2016/35 (RegData_8014 versión 4.3), FEDEA e Instituto de Análisis Económico (CSIC), accessed 18 April 2017 at http://www.fedea.net/ datos-economia-regional-y-urbana/.

De Lucas, J., M.J. Añón, A. Galiana, J. García, R. Mestre, P. Miravet, et al. (2008), Los derechos de participación como elemento de integración de los inmigrantes, Fundación BBVA, Informes 2008, Economía y Sociedad, Bilbao.

Fernández Macías, E. and C. Vacas-Soriano (2016), 'A coordinated EU minimum wage policy?', European Journal of Industrial Relations, 22 (2), 97-113.

Ferrera, M. (1996), 'The "Southern Model" of welfare in social Europe', Journal of European Social Policy, 6 (1), 17-37.

Government of Spain (2017), 'Stability Program Update for the Kingdom of Spain 2017-2020', accessed 2 January 2019 at https://ec.europa.eu/info/sites/info/files/2017-european-semesterstability-programme-spain-en.pdf.

Inklaar, R. and M.P. Timmer (2012), 'The relative price of services', Review of Income and Wealth, $60(4), 727-46$.

International Labour Office (ILO) (2017), 'Fourth Supplementary Report: Report of the Committee set up to examine the representation alleging non-observance by Spain of the Minimum Wage Fixing Convention, 1970 (No. 131)', submitted under article 24 of the ILO Constitution by the Trade Union Confederation of Workers' Committees (CCOO) and the General Union of Workers (UGT), Governing Body 329th Session, Geneva, 9-24 March, reference GB.329/ INS/20/4test data.

Juliá, S. (2018), Transición. Historia de una política española (1937-2017), Barcelona: Galaxia Gutenberg. 
Kuznets, S. (1955), 'Economic growth and income inequality', American Economic Review, 45 (1), $1-28$.

Marglin, S.A. and J. Schor (eds) (1990), The Golden Age of Capitalism. Reinterpreting the Postwar Experience, Oxford: Clarendon Press.

Marino, S., R. Penninx and J. Roosblad (2015), 'Trade unions, immigration and immigrants in Europe revisited: unions' attitudes and actions under new conditions', Comparative Migration Studies, 3 (1), 1-16.

Miravet, P. (2008), 'Trabajadores inmigrantes, sindicatos y participación, Los derechos de participación como elemento de integración de los inmigrantes', II Convocatoria de Ayudas a la Investigación en Economía, demografía y Estudios de Población y Estudios Europeos de la Fundación BBVA.

Moreno, L. (ed.) (2009), Las reformas de las políticas de bienestar social en España, Madrid: Siglo XXI.

Muñoz de Bustillo, R. (2014), 'Questioning the myth of expansionary austerity: European macroeconomic policy during the crisis and its aftermath', in J. Bilbao Ubillos (ed.), The Economic Crisis and Governance in the European Union. A Critical Assessment, London: Routledge, pp. 114-33.

Muñoz de Bustillo, R. (2016), 'Algunas consideraciones generales sobre la desigualdad de ingresos en el caso español', Tiempo de Paz, no. 121 (Summer), 51-8.

Muñoz de Bustillo, R. and J.I. Antón (2010), 'From sending to host societies: immigration in Greece, Ireland and Spain in the 21st century', Industrial Relations Journal, 46 (6), 563-83.

Muñoz de Bustillo, R. and J.I. Antón (2012), 'Immigration and labour market segmentation in Europe', in E. Fernández-Macías, D. Storrie and J. Hurley (eds), Transformations of the Employment Structure in the EU and US, 1995-2007, London: Palgrave, pp. 111-46.

Muñoz de Bustillo, R. and F. Pinto (2017), 'Industrial relations and inequality in the Spanish labour market: resilience and change', in D. Vaughan-Whitehead (ed.), Reducing Inequalities in Europe: How Industrial Relations and Labour Policies Can Close the Gap, Cheltenham, UK and Northampton, MA, USA: Edward Elgar and Geneva: ILO, pp.471-518.

Organisation for Economic Co-operation and Development (OECD) (1994), The OECD Jobs Study. Facts, Analysis, Strategies, Paris: OECD.

Organisation for Economic Co-operation and Development (OECD) (2001), Estudios económicos de la OCDE: España 2001, Paris: OECD.

Organisation for Economic Co-operation and Development (OECD) (2004), Employment Outlook 2004, Paris: OECD.

Organisation for Economic Co-operation and Development (OECD) (2017), OECD Compendium of Productivity Indicators 2017, Paris: OECD.

Osberg, L. and A. Sharpe (1998), 'An Index of Economic Well-being for Canada', research report, Applied Research Branch, Human Resources Development Canada, Hull, December.

Osberg, L. and A. Sharpe (2002), 'An Index of Economic Well-being for selected OECD countries', Review of Income and Wealth, 48 (3), 291-316.

Osberg, L. and A. Sharpe (2016), 'Database of the Index of Economic Well-being for selected OECD countries and Alberta, 1980-2014', updated May 2016, accessed 8 December 2017 at http://www.csls.ca/iwb/oecd.asp.

Penninx, R. and J. Roosblad (eds) (2000), Trade Unions, Immigration, and Immigrants in Europe, 1960-1993: A Comparative Study of the Attitudes and Actions of Trade Unions in Seven West European Countries, New York and Oxford: Berghahn Books.

Ramos, R. (2014), 'Turning a corner? How Spain can help immigrants find middle-skilled work', report, Migration Policy Institute and International Labour Office, Washington, DC and Geneva.

Raymond, J.L. and B. García Greciano (1996), 'Distribución regional de la renta y movimientos migratorios', Papeles de Economía Española, 67, 185-201.

Rodrik, D. (2004), 'Institutions and economic performance - getting institutions right', CESifo DICE Report, 2 (2), 10-15.

Rodrik, D. and A. Subramanian (2003), 'The primacy of institutions (and what this does and does not mean)', Finance and Development, 40 (2), 31-4. 
Sachs, J. (1997), 'Nature, nurture and growth', The Economist, 12 June, 20-24.

Schulten, T. (2008), 'Towards a European minimum wage policy? Fair wages and social Europe', European Journal of Industrial Relations, 14 (4), 421-39.

Stovicek, K. and Turrini, A. (2012), 'Benchmarking unemployment benefit systems', European Economy Economic Papers No. 454, May, Brussels.

Stückow, I. (2012), 'Undocumented workers in Spain and the politics of regularization', Center for Migration and Citizenship, May.

Unión General de Trabajadores y Comisiones Obreras (1990), 'Propuesta sindical prioritaria', Politica y Sociedad, 5, 73-87.

United Nations (UN) (2015), Trends in International Migrant Stock: Migrants by Destination and Origin, New York: UN Population Division. 